\title{
INFLUÊNCIA DA COMMON LAW NA IMPLANTAÇÃO DOS PRECEDENTES JUDICIAIS VINCULANTES NO BRASIL NA ERA DA SOCIEDADE DA INFORMAÇÃO
}

\author{
INFLUENCE OF THE COMMON LAW IN THE IMPLANTATION OF STARE
} DECISIS IN BRAZIL IN THE AGE OF THE INFORMATION SOCIETY

\author{
INFLUENCIA DE COMMON LAW EN LA IMPLANTACIÓN DE LOS \\ PRECEDENTES JUDICIALES VINCULANTES EN BRASIL EN LA ERA DE LA \\ SOCIEDAD DE LA INFORMACIÓN
}

\begin{abstract}
MARCELO GUERRA MARTINS
http://orcid.org/0000-0002-3176-229X / http://lattes.cnpq.br/9367234292369681 / marcelo.martins@fmu.br Faculdades Metropolitanas Unidas, São Paulo, São Paulo, Brasil.
\end{abstract}

GUSTAVO FILIPE BARBOSA GARCIA

http://orcid.org/0000-0003-2709-5938 / http://lattes.cnpq.br/7943230278825301 / gustavofbg@yahoo.com.br Faculdades Metropolitanas Unidas, São Paulo, São Paulo, Brasil.

Augusto TAVARES ROSA MARCACINI http://orcid.org/0000-0002-0459-0744 / http://lattes.cnpq.br/1087306662489365 / amarcacini@gmail.com São Paulo, São Paulo, Brasil.

\begin{abstract}
RESUMO
O presente artigo tem por objetivo abordar a influência de alguns institutos originários da common law na criação de um sistema de precedentes judiciais vinculantes dentro do ordenamento jurídico brasileiro, no contexto atual da sociedade da informação. Para tanto, são analisadas as principais diferenças entre a civil law e a common law, inclusive em termos históricos, concluindo-se que institutos como certionari, stare decisis, distinguishing e overruling encontram-se atualmente incorporados nas regras do processo civil brasileiro. São também expostas as vantagens trazidas pelos precedentes vinculantes (isonomia, segurança jurídica, impessoalidade e racionalidade na utilização do Poder Judiciário). Em termos de metodologia, trata-se de um estudo teórico (revisão bibliográfica e de legislação), com predominância do método qualitativo de análise de dados e resultados, sendo as conclusões essencialmente obtidas pelo emprego da indução.
\end{abstract}

Palavras-chave: civil law; common law; precedentes judiciais vinculantes; sociedade da informação.

\begin{abstract}
This paper aims to address the influence of some common law institutes in the creation of a stare decisis system in the Brazilian law, within the context of the information society. Therefore, the main differences between a civil law and a common law are analyzed, including historical terms, and it is concluded that institutes such as certionari stare decisis, distinguishing and overruling were now incorporated in the rules of Brazilian civil procedure. The advantages of adopting the stare decisis (isonomy, legal security, impersonality and rationality in the use of the Judiciary) are also analysed. In terms of methodology, this is a theoretical study, with predominance of the qualitative method of data analysis and results, being as conclusions essentially obtained by the use of induction.
\end{abstract}

Keywords: civil law; common law; stare decisis; information society. 


\section{RESUMEN}

El presente artículo tiene por objetivo abordar la influencia de algunos institutos originarios de la common law en la creación de un sistema de precedentes judiciales vinculantes dentro del ordenamiento jurídico brasileño, en el contexto actual de la sociedad de la información. Para ello, se analizan las principales diferencias entre la civil law y la common law, incluso en términos históricos, concluyendo que institutos como certionari, stare decisis, distinguishing y overruling se encuentran actualmente incorporados en las reglas del proceso civil brasileño. También se exponen las ventajas aportadas por los precedentes vinculantes (isonomía, seguridad jurídica, impersonalidad y racionalidad en la utilización del Poder Judicial). En términos de metodología, se trata de un estudio teórico (revisión bibliográfica y de legislación), con predominio del método cualitativo de análisis de datos y resultados, siendo las conclusiones esencialmente obtenidas por el empleo de la inducción.

Palabras clave: civil law; common law; precedentes judiciales vinculantes; sociedad de la información.

\section{SUMÁRIO}

INTRODUÇAO; 1 AS DUAS GRANDES FAMÍLIAS DO DIREITO OCIDENTAL; 2 PRECEDENTES JUDICIAIS VINCULANTES COMO CATALIZADORES DE ISONOMIA, SEGURANÇA JURÍDICA E OUTROS BENEFÍCIOS INSTITUCIONAIS; 3 LONGO CAMINHO RUMO À UNIFORMIZAÇÃO DA JURISPRUDÊNCIA NO BRASIL; 3.1 Antecedentes remotos da uniformização de jurisprudência no direito luso-brasileiro; 3.2 Legislações estaduais e o Código de Processo Civil de 1939; 3.3 o Código de Processo Civil de 1973; 3.3 .1 Incidente de uniformização de jurisprudência e de arguição de inconstitucionalidade; 3.3 .2 Lei 9.756/98 e o julgamento monocrático nos Tribunais; 3.4 Emenda 45/2004 e as Leis 11.418/2006 e 11.672/2008: súmula vinculante, repercussão geral e recurso representativo de controvérsia; 3.50 Código de Processo Civil de $2015 ; 3.5 .1$ Julgamento de improcedência sem a citação do réu; 3.5.2 Introdução do stare decisis, distinguishing e overruling; 3.5.3 Julgamento monocrático nos Tribunais; 3.5.4 Incidente de assunção de competência; 3.5.5 Incidente de arguição de inconstitucionalidade; 3.5.6 Incidente de resolução de demandas repetitivas; 3.5.7 Suspensão de processos por afetação de recurso extraordinário ou especial repetitivos; 4 BREVES COMENTÁRIOS CRÍTICOS ACERCA DO TEMA; CONCLUSÃO; REFERÊNCIAS.

\section{INTRODUÇÃO}

O presente texto é fruto de projeto desenvolvido no âmbito do Mestrado em Direito do Centro Universitário das Faculdades Metropolitanas Unidas ${ }^{1}$, tendo como pano de fundo a denominada sociedade da informação, período histórico vivido pela humanidade em que criação, processamento, armazenagem, proteção e difusão do conhecimento desempenham papel de alto relevo nos principais arranjos socioeconômicos dos diversos países.

Com efeito, na "era do conhecimento, a informação e o conhecimento são os atores centrais da produção econômica"2. No mesmo sentido, Roberto Senise Lisboa ${ }^{3}$ assinala que

\footnotetext{
1 Linha de pesquisa 2: Decisão Jurídica e Monopólio do Estado (Projeto 4: Cidadania e Controle Social no Estado Democrático de Direito).

2 SIQUEIRA JÚNIOR, Paulo Hamilton. Habeas data: remédio jurídico da sociedade da informação. In: PAESANI, Liliana Minardi (Coord.). 0 direito na sociedade da informação. São Paulo: Atlas, 2007, p. 255.

${ }^{3}$ LISBOA, Roberto Senise. O consumidor na sociedade da informação. In: PAESANI, Liliana Minardi (Coord.). O direito na sociedade da informação. São Paulo: Atlas, 2007, p. 121.
} 
ISSN 1981-3694

(DOI): $10.5902 / 1981369431054$

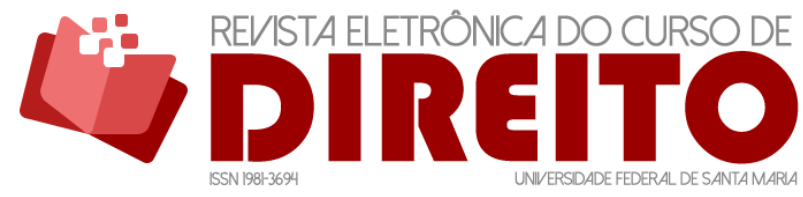

INFLUÊNCIA DA COMMON LAW NA IMPLANTAÇÃO DOS PRECEDENTES JUDICIAIS VINCULANTES NO BRASIL NA ERA DA SOCIEDADE DA INFORMAÇÃO

MARCELO GUERRA MARTINS GUSTAVO FILIPE BARBOSA GARCIA AUGUSTO TAVARES ROSA MARCACINI

atualmente "os ativos do conhecimento, isto é, o capital intelectual, passaram a ser mais importantes para as empresas que os ativos financeiros e físicos". Tanto assim é que, por exemplo, "a propriedade intelectual é o maior produto de exportação dos Estados Unidos"4. Aliás, no final do século passado, Alvin Toffler já apregoava que "a informação tornou-se talvez o negócio mais importante e o que mais cresce no mundo".

Entretanto, não é apenas o protagonismo do conhecimento de cunho econômico que está em jogo, visto que a sociedade da informação também se caracteriza pela crescente circulação, em termos mundiais, de ideias, opiniões, informações e cultura em geral, fenômeno que ganhou notável impulso após a popularização da internet nos anos 1990 que, como sabido, reduziu drasticamente os custos de comunicação à distância.

Nessa perspectiva, segundo Manuel Castells ${ }^{6}$, a internet se mostra como "um meio de comunicação que permite, pela primeira vez, a comunicação de muitos com muitos, num momento escolhido, em escala global". Fato é que "as pessoas, como nunca antes, estão utilizando telefones fixos e móveis e acessando a internet para desfrutar da riqueza das informações e aplicações que isso proporciona"7. É possível afirmar, portanto, que a "era global não está à frente de nós, mas já estamos nela"8, sendo certo que, na lição de Pierre Lévy, o “surgimento do ciberespaço acompanha, traduz e promove a evolução geral da civilização"9.

Essa conjuntura de intensificação comunicacional entre os povos tem gerado reflexos nos vários ordenamentos jurídicos ao redor do mundo que, de forma crescente, passam a influenciar-se mutuamente, e isso muito se dá por causa de um notório aguçamento do interesse de estudantes, professores, advogados, juízes, enfim, dos profissionais do direito, por institutos jurídicos típicos de outras terras. Com efeito, segundo Hein Kotz, "não há dúvida de que as

\footnotetext{
${ }^{4}$ FORGIONI, Paula A. Fundamentos do antitruste. 8. ed. São Paulo: Revista dos Tribunais, 2015, p. 313.

5 TOFFLER, Alvin. A terceira onda. 18. ed. São Paulo: Record, 1980, p. 162). Em termos de economia atual, Paula Forgioni menciona que "a propriedade intelectual é o maior produto de exportação dos Estados Unidos".

${ }^{6}$ CASTELLS, Manuel. A galáxia da internet. Trad. Maria Luiza X. de A. Borges. Rio de Janeiro: Zahar, 2003, p. 08.

7 UNITED NATIONS. Economic and Social Commission for Western Asia. Information society measurement: building a common benchmarking model for the ESCWA region. New York: United Nations, 2011, p. 02. O texto original é o seguinte: "More people than ever before are using fixed and mobile phones and accessing the Internet, tapping the wealth of information and applications it provides".

${ }^{8}$ MATTELART, Armand. The information society. Trad. $\mathrm{p} /$ ingles Susan $\mathrm{G}$ Taponier e James A. Cohen. London: SAGE Publications, 2003, p. 91. 0 texto original é o seguinte: "The global age is not ahead of us; we are already in it".

${ }_{9}^{9}$ LÉVY, Pierre. Cyberculture. Trad. p/ ingles de Robert Bononno. Minneapolis: University of Minesota Press, 2001, p.07.
} 
ISSN 1981-3694

(DOI): $10.5902 / 1981369431054$

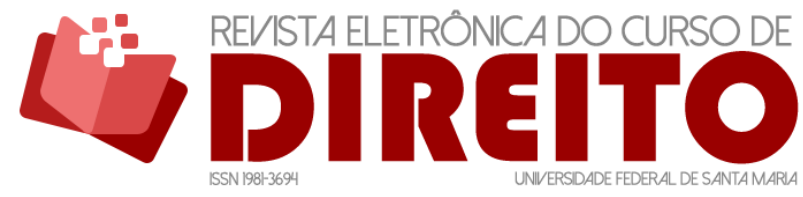

INFLUÊNCIA DA COMMON LAW NA IMPLANTAÇÃO DOS PRECEDENTES JUDICIAIS VINCULANTES NO BRASIL NA ERA DA SOCIEDADE DA INFORMAÇÃO

MARCELO GUERRA MARTINS GUSTAVO FILIPE BARBOSA GARCIA AUGUSTO TAVARES ROSA MARCACINI

jovens gerações de juristas se depararão com uma nunca antes vista internacionalização da vida legal”10, daí a importância de estudos ligados à comparação jurídica.

É exatamente nesse ponto que reside o problema a ser investigado no presente artigo: a influência de institutos típicos da common law na criação de um sistema de precedentes judiciais vinculantes dentro do ordenamento brasileiro, precipuamente forjado sob a civil law.

Nosso objetivo é identificar pontos de aproximação entre institutos da common law, e o direito brasileiro, relacionados com o sistema de precedentes, bem como de que maneira e em qual cadência essa agregação está sendo feita, além de tecer considerações de índole valorativa a respeito do fenômeno que acreditamos ser inegável, conforme será explicado.

No desenrolar do trabalho serão abordados os seguintes tópicos: características essenciais da civil law e da common law, inclusive no que se refere aos aspectos históricos; precedentes judiciais vinculantes como catalizadores de isonomia, segurança jurídica, impessoalidade e utilização racional do Poder Judiciário; o longo caminho rumo à uniformização da jurisprudência no Brasil, desde o Código de 1939 até os dias atuais e, dentre as principais conclusões, a de que o ordenamento brasileiro adotou, notadamente após o Código de 2015, disposições que se aproximam a institutos originados na common law, tais como stare decisis, distinguishing e overruling.

Em termos de metodologia, o texto se apresenta como um estudo teórico (revisão bibliográfica e de legislação), com análise de índole qualitativa, dado que os resultados e conclusões, obtidos principalmente pelo método da indução, necessitam de considerações valorativas e de interpretação. Naturalmente, não é intento dos autores trazerem palavras finais muito menos fixar certezas, sendo certo que eventuais críticas são esperadas e bem-vindas.

\section{AS DUAS GRANDES FAMÍLIAS DO DIREITO OCIDENTAL}

No mundo ocidental, os subsistemas de direito dos diversos países costumam ser divididos em duas famílias principais: a civil law e a common law. ${ }^{11}$ Diz-se ocidental porque, como bem sabido, em diversos locais há “outras concepções da ordem social e do direito, tais

\footnotetext{
${ }^{10}$ KOTZ, Hein. The Function of Comparative Law in the Development of a European Common Law. Asia Pacific Law Review, 45, 1994, p.46. O texto original é o seguinte: "there is no doubt that the younger generation of lawyers will be faced with an unparalleled 'internationalisation' of legal life".

11 HAMILTON, Peter J. The civil law and the common law. Harvard Law Review, v. 36, n. 2, p. 180.
} 
ISSN 1981-3694

(DOI): $10.5902 / 1981369431054$

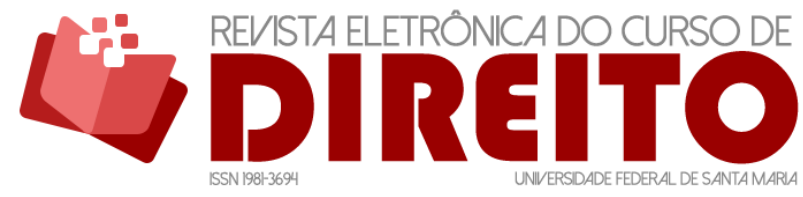

INFLUÊNCIA DA COMMON LAW NA IMPLANTAÇÃO DOS PRECEDENTES JUDICIAIS VINCULANTES NO BRASIL NA ERA DA SOCIEDADE DA INFORMAÇÃO

MARCELO GUERRA MARTINS GUSTAVO FILIPE BARBOSA GARCIA AUGUSTO TAVARES ROSA MARCACINI

como o direito muçulmano, indiano, direitos do Extremo Oriente, direito judaico, direitos da África e de Madagascar, de forte componente ligado à religião"12.

A chamada civil law, que inspirou e deu origem à maior parte do direito europeu continental e latino-americano, tem origem remota nos preceitos de direito romano posteriormente compilados e sistematizados por glosadores medievais. A primeira grande compilação foi engendrada a mando de Justiniano ${ }^{13}$ que, "objetivando fortalecer as bases de seu poder imperial e o direito romano, que estavam sob ameaça de invasão bárbara no oriente, determinou a compilação das leis então existentes em um único diploma, denominado Corpus luris Civilis"14.

Muito tempo depois, segundo Teresa Arruda Alvim Wambier, “no século XI, descobriramse textos jurídicos romanos, que haviam sido conservados durante a Idade Média, e começaram a ser restaurados no norte da Itália, principalmente em Bologna” ${ }^{15}$. No caso, a compilação visou edificar um corpo sistêmico com vistas a conferir harmonia e racionalidade aos textos romanos originais que, em suma, se revelavam como um apanhado extenso e variado de decisões prolatadas, caso a caso, pelos antigos pretores, bem como normas costumeiras e normas escritas esparsas e sem conexão aparente ${ }^{16}$.

Dessa maneira, "o direito dos países de civil law nasceu como um fruto de refinado trabalho intelectual e não do pensamento do homem comum"17, encontrando-se impregnada a intenção de se construir um sistema racional e lógico. Assim, nas "universidades medievais, estudantes (futuros juízes, advogados e legisladores) e professores antes estavam preocupados

12 SOARES, Guido Fernando da Silva. Common law: introdução ao direito dos EUA. 2. ed. São Paulo: Revista dos Tribunais, 2000, p. 25.

13 Os textos foram coligidos por uma comissão criada pelo imperador Justiniano e foram divulgados na década de 530 d.C. (LOPES, José Reinaldo de Lima, et. al. Curso de história do direito. 2. ed. São Paulo: Método, 2009, p. 29).

14 ARAÚJO, Francisco Rossal de; BRANDENBURG, Marceli. Sistemas abertos e fechados: uma breve comparação entre os sistemas da common law e civil law. Justiça do Trabalho, ano 32, n. 384, dez. 2015, p. 8.

${ }_{15}$ WAMBIER, Teresa Arruda Alvim. Interpretação da lei e de precedentes - civil law e commom law. In: ADEODATO, João Maurício; BITTAR, Eduardo C. B. (orgs.). Filosofia e teoria geral do direito: estudos em homenagem a Tercio Sampaio Ferraz Júnior pelo seu septuagésimo aniversário. São Paulo: Quartier Latin, 2011, p. 1063.

16 SOARES, Guido Fernando da Silva, op. cit., p. 27; WAMBIER, Teresa Arruda Alvim, ob. cit., p. 1064. É certo que o "direito positivado em lei já existia em Roma e, em certa medida, persistiu na Idade Média em decorrência do direito canônico. Gradualmente, a positivação ganha força com a edição de comandos legais, na medida em que se tem a unicidade do poder normativo concentrado nos parlamentos". AZEVEDO NETO, Floriano Marques de. O direito administrativo no sistema de base romanística e de common law. Revista de Direito Administrativo, v. 268, jan./abr. 2015, p. 60.

17 WAMBIER, Teresa Arruda Alvim, op. cit., p. 1064. 
ISSN 1981-3694

(DOI): $10.5902 / 1981369431054$

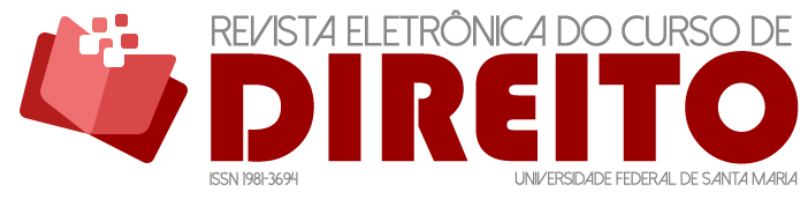

INFLUÊNCIA DA COMMON LAW NA IMPLANTAÇÃO DOS PRECEDENTES JUDICIAIS VINCULANTES NO BRASIL NA ERA DA SOCIEDADE DA INFORMAÇÃO

MARCELO GUERRA MARTINS GustaVO FILIPE BARBOSA GARCIA AUGUSTO TAVARES ROSA MARCACINI

com a racionalidade e logicidade do sistema, do que com os reais efeitos da aplicação da norma" ${ }^{18}$.

Desse contexto, derivou a importância do papel desenvolvido pela doutrina nos sistemas de civil law, cuja característica marcante, desde os tempos da escola de Bolonha, foi um grande apego à literalidade dos textos normativos ${ }^{19}$. Aliás, atualmente a doutrina ainda exerce um papel de relevo nos países de civil law ${ }^{20}$, diferentemente do que se observa nos locais de predomínio da common law, onde a doutrina tem papel coadjuvante ou de secondary authority ${ }^{21}$. Nessa linha, há mais de um século, Ezra R. Thayer assim apregoou: “Em caso de algum conflito entre a teoria e os métodos tradicionais, os Tribunais têm convenientemente sido capazes de proceder segundo seus antecessores em detrimento da teoria"22.

Grande impulso a essa concepção decorreu da eclosão da Revolução Francesa de 1789 que, como sabido, representou uma quebra de paradigma no que se refere à divisão dos Poderes do Estado, instaurando-se uma diferenciação clara das funções exercidas pelo Legislativo, Executivo e Judiciário, com inspiração nas ideias de Mostesquieu. Como a intenção era romper os vínculos com o antigo regime, a função criadora do direito foi definitivamente concentrada no Poder Legislativo, cujas normas (as leis) deveriam ser as únicas fontes legítimas do direito.

$\mathrm{Na}$ França pré-revolucionária a magistratura era parte do aparato de poder da aristocracia $^{23}$ e em seu benefício costumava decidir, daí a necessidade de limitar os poderes dos juízes obrigando-os a decidir seguindo estritamente os textos legais. Desse modo, não poderiam mais os juízes interpretar as leis, muito menos aplicar direitos que vigoravam durante o ancien

\footnotetext{
18 SOARES, Guido Fernando da Silva, op. cit., p. 28.

19 Com efeito, o curso ministrado pelo monge Irnerius, talvez principal expoente da escola de Bologna, "detinha dentre suas características a fidelidade ao texto justinianeu, posto que, acreditava-se que nele encontrariam a Lei da Igreja, devendo por tal razão ser restringida a interpretação de seus dogmas de forma analítica, ou seja, a atividade dos juristas deveria ser unicamente a interpretação literal dos textos ali contidos". ARAÚJO, Francisco Rossal de; BRANDENBURG, Marceli, op. cit., p. 8.

${ }^{20}$ GARAPON, Antoine; PAPAPOULOS, Ioannis. Julgar nos Estados Unidos e na França: cultura jurídica francesa e common law em uma perspectiva comparada. Trad. Regina Vasconcelos. Rio de Janeiro: Lumen Juris, 2008, p. 35.

${ }^{21}$ SOARES, Guido Fernando da Silva, op. cit., p. 73.

22 THAYER, Ezra R. Thayer. Judicial legislation: its legitimate function in the development of the common law. Harvard Law Review, vol. 5, n. 4, nov. 1891, p. 180. 0 texto original é o seguinte: "In case of any conflict between theory and the traditional methods, the courts have been able conveniently to slough the former, and have proceeded as their predecessors did before them".

${ }^{23}$ DALLARI, Dalmo de Abreu. 0 poder dos juízes. São Paulo: Saraiva, 1996, p. 14. Na mesma página o autor esclarece que o ofício dos juízes era considerado direito de propriedade, quer dizer, "a magistratura poderia ser comprada, vendida, transferida por herança, ou mesmo alugada [...] 0 ofício era rendoso, pois a prestação de justiça era paga, havendo muitos casos de cobrança abusiva".
} 
ISSN 1981-3694

(DOI): $10.5902 / 1981369431054$

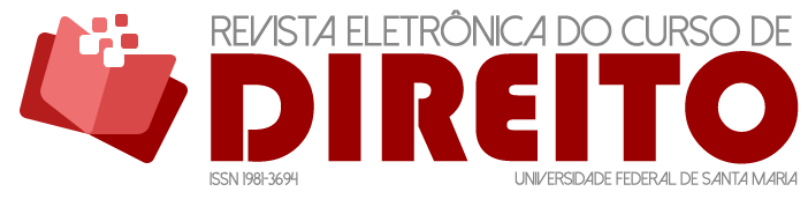

INFLUÊNCIA DA COMMON LAW NA IMPLANTAÇÃO DOS PRECEDENTES JUDICIAIS VINCULANTES NO BRASIL NA ERA DA SOCIEDADE DA INFORMAÇÃO

MARCELO GUERRA MARTINS GUSTAVO FILIPE BARBOSA GARCIA AUGUSTO TAVARES ROSA MARCACINI

régime, nem tão pouco se socorrem de preceitos do direito romano em suas decisões ${ }^{24}$. Passaram os juízes a serem la bouche de la loi, quer dizer, deveriam apenas proclamar o texto da lei que, por ser geral e abstrato, valeria para todos de igual maneira, sem distinção de qualquer ordem, pondo fim a qualquer eventual privilégio nobiliário ou clerical perante os Tribunais.

Com isso, na linha do chamado positivismo jurídico, o direito passou a ser considerado válido e, assim, obrigatório, se proveniente de determinado órgão (o Parlamento) e mediante o cumprimento de regras certas para sua edificação (o processo legislativo). Nesse ponto, o positivismo atendeu a um anseio das classes dedicadas ao comércio em geral (a burguesia) por maior segurança jurídica, clareza e estabilidade das normas, visto que o direito passara a ter apenas uma única e exclusiva fonte, a lei editada pelo Parlamento e nada mais ${ }^{25}$.

O exemplo mais retumbante do ideal jus-positivista foi o Código de Napoleão de 1804, que intentava abranger todas as situações passíveis de ocorrer no meio social, dispensando-se, por conseguinte, a interpretação de seus preceitos pelos juízes (art. $5^{\circ}$ ). Cada juiz deveria decidir por si, sendo inconcebível a ideia da formação de uma jurisprudência que pudesse fundamentar decisões.

Ocorre que fatores como a eclosão do constitucionalismo no século XIX, bem como a crescente complexidade das relações jurídicas, econômicas e sociais em diversos países, aos poucos foram gerando uma crescente necessidade de composição entre os grupos de interesse predominantes em certos momentos, de modo a permitir 0 atingimento de maiorias parlamentares e, com isso, terem seus anseios atendidos, mesmo que parcialmente. Desse amalgamento de vontades e interesses contrapostos, principalmente a partir da segunda metade do século XX, emergiu uma legislação de índole excessivamente genérica, ambígua, obtusa e contraditória em muitos pontos e, sobretudo, de índole principiológica. É o que ocorre, por exemplo, com expressões como: dignidade da pessoa humana, de modo exagerado, em desacordo com a razoabilidade, etc.

Os juízes não raramente passaram a ter que se desapagar da literalidade do texto legal para, em suas decisões e sentenças, inserirem considerações interpretativas que conferissem sentido à norma em jogo, sob pena de imprestabilidade (ou ineficácia) do veredicto. E, como nessa atividade criadora dos juízes sempre houve o emprego de sentimentos morais e convicções

\footnotetext{
${ }^{24}$ WAMBIER, Teresa Arruda Alvim, op. cit., p. 1064.

${ }^{25}$ Anteriormente à Revolução, a França convivia com "vários direitos". Ao norte, predominava um direito oriundo da consolidação de costumes germânicos. Ao sul, protagonizava do direito romano. Havia também o direito canônico com competência para julgar questões matrimoniais, filiação e testamentos (RÁO, Vicente. 0 direito e a vida dos direitos. 3. ed. São Paulo: Revista dos Tribunais, 1991, vol. 1, p. 77).
} 
ISSN 1981-3694

(DOI): $10.5902 / 1981369431054$

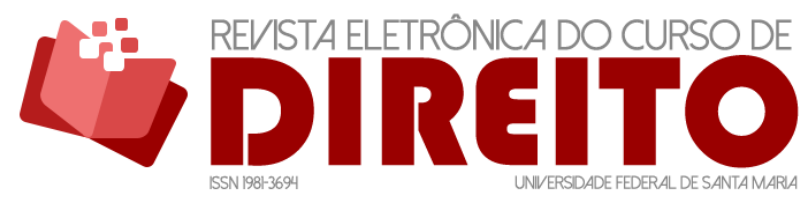

INFLUÊNCIA DA COMMON LAW NA IMPLANTAÇÃO DOS PRECEDENTES JUDICIAIS VINCULANTES NO BRASIL NA ERA DA SOCIEDADE DA INFORMAÇÃO

MARCELO GUERRA MARTINS GUSTAVO FILIPE BARBOSA GARCIA AUGUSTO TAVARES ROSA MARCACINI

estritamente pessoais, sabidamente muito variáveis de pessoa para pessoa, a lei passou ser aplicada das formas as mais diversas, muitas vezes de modo antagônico, tudo a depender de quem julgou determinado caso.

Em suma, segurança jurídica, previsibilidade e isonomia de tratamento buscada pelo sistema da civil law restou severamente prejudicada, ao menos em países como o Brasil $^{26}$ que originalmente não contavam com mecanismos de fechamento da interpretação última do direito por cortes judiciais superiores, como há tempos ocorre na common law, a seguir abordada.

Conforme John Gilissen, dá-se "o nome de common law ao sistema jurídico que foi elaborado em Inglaterra a partir do século XII pelas decisões das jurisdições reais”27. É que, não obstante os duques normandos terem, em 1.066, vencido a guerra pelo trono inglês com a vitória de Guilherme I na Batalha de Hastings, não possuíam poderio militar suficiente para se imporem sobre "os diversos núcleos de poder existentes nos diferentes condados e lands da Inglaterra" 28 que, ao menos num primeiro momento, por meio de seus chefes e sheriffs, permaneceram decidindo conflitos com esteio nas regras e costumes locais, o chamado direito anglo-saxônico ${ }^{29}$.

Somete no ano de 1.154, no reinado de Henrique II, é que ocorre a unificação do sistema judicial (Jurisdição da Coroa) e a consequente suplantação dos poderes das jurisdições locais, daí se originando a expressão common law, ou seja, direito comum a todos e aplicado pelos juízes em nome do rei ${ }^{30}$. Antigas regras, estatutos e costumes locais foram sendo paulatinamente amalgamados e condensados num edifício jurídico uniforme composto primordialmente pelas decisões proferidas pelas cortes reais ao longo dos tempos. Esse cenário conferiu à common law "raízes profundamente pragmáticas e desapegadas de qualquer

26 A divergência jurisprudencial no Brasil é fenômeno notório e antigo. Aliás, o "próprio STJ tem entendimentos diferentes a respeito de casos iguais. Isso ocorre não só quando uma Turma diverge da outra. Uma mesma Turma, não raras vezes, não mantém estável determinada decisão". MARINONI, Luiz Guilherme. A ética dos precedentes: justificativa do novo CPC. 2. ed. São Paulo: Revista dos Tribunais, 2016, p. 71.

27 GILISSEN, John. Introdução histórica ao direito. Trad. A. M. Hespanha e L. M. Macaísta Malheiros. Lisboa: Fundação Calouste Gulbenkian, 1988, p. 207. Segundo SOARES, Guido Fernando da Silva (ob. cit, p. 52), considera-se da família de common law, além da Inglaterra, os seguintes países: Austrália, Nova Zelândia, Canadá, Índia, Paquistão, Bangladesh, Quênia, Nigéria, Hong Kong, Guiana, Trinidad e Tobado, Barbados. Adotam um sistema misto, com forte influência da common law, os Estados Unidos (com exceção do Estado de Lousiana - que adota a civil law). Igualmente adotam um sistema misto, mas com predominância da civil law, a Escócia, Israel, África do Sul e Filipinas).

${ }^{28}$ AZEVEDO NETO, Floriano Marques de, op. cit., p. 62-63.

29 Nessa época, "o sistema jurídico vigente mantinha a essência híbrida dos Romanos, com traços da cultura anglo-saxônica, sendo formado por leis escritas, pelos Costumes locais e pelo direito canônico, este último incorporado pelos normandos". ARAÚJO, Francisco Rossal de; BRANDENBURG, Marceli, ob. cit., 14.

${ }^{30}$ AZEVEDO NETO, Floriano Marques de, op. Cit., p. 63. 
ISSN 1981-3694

(DOI): $10.5902 / 1981369431054$

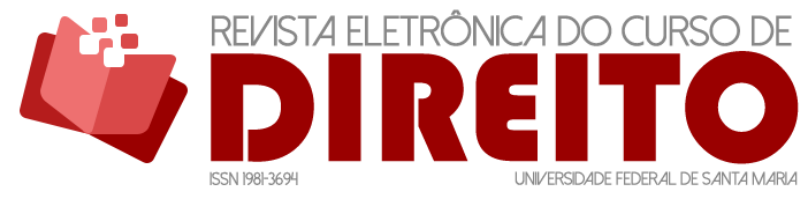

INFLUÊNCIA DA COMMON LAW NA IMPLANTAÇÃO DOS PRECEDENTES JUDICIAIS VINCULANTES NO BRASIL NA ERA DA SOCIEDADE DA INFORMAÇÃO

MARCELO GUERRA MARTINS GUSTAVO FILIPE BARBOSA GARCIA AUGUSTO TAVARES ROSA MARCACINI

compromisso com modelos abstratos (comparativamente à tendência da família dos direitos romanos-germânicos) e influenciados pelo método indutivo"31.

De maneira diversa ao que eventualmente se propaga nas academias, o direito escrito (statute law) possui forte presença em países de common law ${ }^{32}$. Porém, nunca houve uma clara preocupação em se construir estatutos (ou codificações) que se revelassem um sistema normativo hierarquizado lógico-dedutivo, de caráter geral e abstrato, como ocorreu com sistemas de civil law de inspiração romano-gemânica. Nesse sentido, a common law se revela mais como "uma sequência ininterrupta de soluções práticas"33.

Além disso, as normas escritas sempre tiveram um papel secundário em common law, pois, de um modo geral, a partir do momento em que uma decisão judicial é tomada, ainda que sua base repouse numa statute law, é a decisão que passa a ser a fonte de referência para a solução de casos futuros, dentro da concepção do judge made law ${ }^{34}$ e da força obrigatória dos precedentes (stare decisis). Em suma, na common law, "a jurisprudência é fonte primeira do direito" 35 .

\section{PRECEDENTES JUDICIAIS VINCULANTES COMO CATALIZADORES DE ISONOMIA, SEGURANÇA JURÍDICA E OUTROS BENEFÍCIOS INSTITUCIONAIS}

A isonomia (ou igualdade) é um tema muito relevante na maioria das sociedades ocidentais. No Brasil, a Constituição Federal de 1988, logo no Preâmbulo, indica a igualdade como um dos valores supremos "de uma sociedade fraterna, pluralista e sem preconceitos". Aliás, a fim de solapar os alicerces do ancien régime, o art. $1^{\circ}$ da Declaração dos Direitos do Homem e do Cidadão, de 1789, preceituou que "Os homens nascem e são livres e iguais em direitos". Com efeito, a isonomia "é como que a pedra de toque do regime republicano" 36 .

\footnotetext{
31 SOARES, Guido Fernando da Silva, op. cit., p. 31.

32 Com efeito, "os reis da Inglaterra legislaram tanto como os reis de França nos séculos XIII e XIV e, em certas épocas, bastante mais que eles. O rei Eduardo I (1271-1307) foi chamado por alguns historiadores do direito inglês, o 'Justiniano inglês' por causa do grande desenvolvimento da legislação no seu reinado; alguns desses statutes permanecem em vigor até os nossos dias”. GILISSEN, John, op. cit. p. 215.

33 GARAPON, Antoine; PAPAPOULOS, loannis, op. cit., p. 40.

34 GILISSEN, John, idem, p. 208.

35 GARAPON, Antoine; PAPAPOULOS, loannis, op. cit., p. 33.

${ }^{36}$ ATALIBA, Geraldo. República e constituição. 2. ed. 4. tir. São Paulo: Malheiros, 2007, p. 160.
} 
ISSN 1981-3694

(DOI): $10.5902 / 1981369431054$

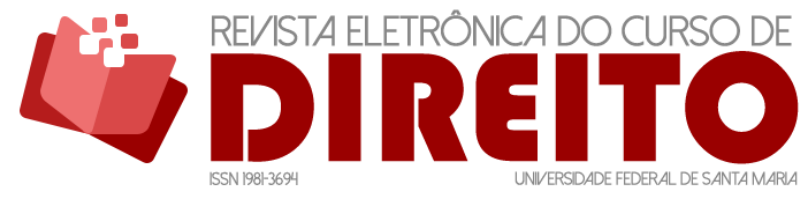

INFLUÊNCIA DA COMMON LAW NA IMPLANTAÇÃO DOS PRECEDENTES JUDICIAIS VINCULANTES NO BRASIL NA ERA DA SOCIEDADE DA INFORMAÇÃO

MARCELO GUERRA MARTINS GUSTAVO FILIPE BARBOSA GARCIA AUGUSTO TAVARES ROSA MARCACINI

No âmbito judicial, isso significa que as questões de direito devem receber interpretação uniforme por parte dos Tribunais $^{37}$, notadamente a partir da observância do já decidido em casos precedentes, assim considerados aqueles que envolvam a mesma normatização jurídica. Em outras palavras, segundo o velho brocardo romano, ubi eadem ratio ibi eadem ius ${ }^{38}$. Com isso, privilegia-se também a impessoalidade nos julgamentos.

Além disso, o respeito aos precedentes majora o nível de previsibilidade do comportamento dos Tribunais, o que, em outras palavras, robustece a segurança jurídica, outro valor de relevo inserido na Constituição Federal de 1988 (v.g., art. 5 , XXXVI). Desse modo, é certo que "os jurisdicionados passam a confiar nas decisões proferidas pelo Judiciário, acreditando que os casos similares terão o mesmo tratamento"39.

Em suma, na lição de Regina Helena $\operatorname{Costa}^{40}$, decidir-se de modo uniforme proporciona: estabilidade, irretroatividade e uniformidade, o que não pode ser ignorado pelo sistema jurídico, pois é muito difícil que haja "desenvolvimento da sociedade que não esteja ancorado num quadro institucional baseado em regras estáveis e legítimas, que propiciem segurança jurídica e recebam aceitabilidade social" ${ }^{41}$.

Evidências empíricas sugerem que países com menor grau de segurança jurídica crescem mais devagar, segundo afirma Armando Castelar Pinheiro ${ }^{42}$. É que em ambientes jurídicoinstitucionais não previsíveis, em que predomina receio e desconfiança em relação ao arcabouço normativo, as pessoas deixam de criar, sentem-se pouco estimuladas a empreender, preferem ficar "quietas em seu canto" a se arriscarem na criação de riqueza nova. Com efeito, nunca se

37 Com efeito, a "justiça do caso concreto deve ser sempre aquela que possa ser assegurada a todos que estão ou possam vir a estar em situação similar, sob pena de quebrar-se a isonomia". AMARAL, Gustavo. Direito, escassez \& escolha. Rio de Janeiro: Renovar, 2001, p. 39.

38 Em tradução livre: "onde existe a mesma razão, aplica-se o mesmo direito".

39 CUNHA, Leonardo Carneiro da. A função do Supremo Tribunal Federal e a força de seus precedentes: enfoque das causas repetitivas. In: PAULSEN, Leandro (coord.). Repercussão geral no recurso extraordinário. Porto Alegre: Livraria do Advogado, 2011, p. 62.

${ }^{40}$ COSTA, Regina Helena. Repercussão geral em matéria tributária: primeiras reflexões. In: PAULSEN, Leandro (coord.). Repercussão geral no recurso extraordinário. Porto Alegre: Livraria do Advogado, 2011, p. 109-110.

41 MICHELS, Gilson Wessler. Desenvolvimento e sistema tributário. In: BARRAL, Welber (org.). Direito e desenvolvimento: análise da ordem jurídica brasileira sob a ótica do desenvolvimento. São Paulo:

Singular, 2005, p. 226.

42 PINHEIRO, Armando Castelar. PIB potencial e segurança jurídica no Brasil. In: SICSÚ, João; MIRANDA, Pedro (orgs.). Crescimento econômico: estratégias e instituições Rio de Janeiro: IPEA, 2009, p. 39. 
ISSN 1981-3694

(DOI): $10.5902 / 1981369431054$

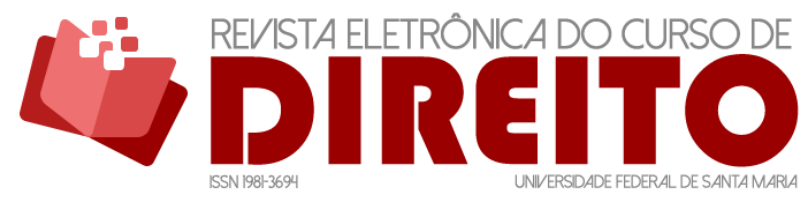

INFLUÊNCIA DA COMMON LAW NA IMPLANTAÇÃO DOS PRECEDENTES JUDICIAIS VINCULANTES NO BRASIL NA ERA DA SOCIEDADE DA INFORMAÇÃO

MARCELO GUERRA MARTINS GUSTAVO FILIPE BARBOSA GARCIA AUGUSTO TAVARES ROSA MARCACINI

pode esquecer que "o grau de investimento está diretamente associado à segurança das relações jurídicas" ${ }^{\prime 3}$.

Outro benefício da previsibilidade do comportamento judicial, por meio de uma jurisprudência uniforme, é a utilização racional do Poder Judiciário, evitando-se o chamado "efeito loteria". Com efeito, o conflito jurisprudencial, do qual resultem chances semelhantes de ganhar ou perder um litígio (o mesmo valendo para a interposição de recursos), o ajuizamento da demanda (ou do recurso) é a atitude mais racional.

O contrário faz igualmente sentido, ou seja, sabendo-se de antemão, com algum grau de certeza, como determinado tema será decidido, pois assim vêm entendo os Tribunais em face do decidido no precedente $X$, muitos litígios podem ser evitados, principalmente se os ônus de sucumbência pelo aforamento de demandas infundadas forem razoáveis. Com isso, o sistema como um todo permanece menos congestionado e, pelo menos teoricamente, mais célere.

Por fim, mas não menos importante, o respeito aos precedentes por juízes e Tribunais também dificulta a utilização do sistema de modo oportunista, seja pelo aproveitamento de contestáveis relações de amizade ou compadrio, seja pelo emprego de mecanismos perturbadoramente ilícitos. Nesse tópico, conforme adverte Luiz Guilherme Marinoni,

[...] determinados litigantes não têm qualquer preocupação com a previsibilidade. Preferem acreditar nas relações de simpatia, estima e influências pessoais, reproduzindo a 'mentalidade cordial' que marcou o sujeito que, provindo de família patriarcal, passou a ocupar o espaço público sem abandonar os seus hábitos ${ }^{44}$.

Os efeitos positivos gerados por uma cultura judicial que acolha a força dos precedentes (isonomia, segurança jurídica, utilização racional do Poder Judiciário e impessoalidade) são suficientes para legitimar a criação de mecanismos jurídicos que fortaleçam esse tipo de comportamento por parte dos juízes brasileiros.

Nos países que seguem a linha do common law, o respeito ao precedente (também chamado de stare decisis) é muito mais natural, ou seja, não foi necessário editar normas específicas que obrigassem os magistrados acompanharem as decisões emanadas dos órgãos superiores do sistema. A própria cultura do common law gerou esse tipo de postura em face do princípio judge made law. Logo, uma decisão oriunda de Corte superior é "lei” para as instâncias

${ }^{43}$ GONÇALVES, Albenir Itaboraí Querubini. O direito brasileiro e a inovação na consolidação de um sistema de precedentes recursais. Revista Eletrônica do Curso de Direito da UFSM, v. 6, n. 3, 2011.

${ }^{44}$ MARINONI, Luiz Guilherme. A ética dos precedentes: justificativa do novo CPC. São Paulo: Revista dos Tribunais, 2016, p. 96. 
ISSN 1981-3694

(DOI): $10.5902 / 1981369431054$

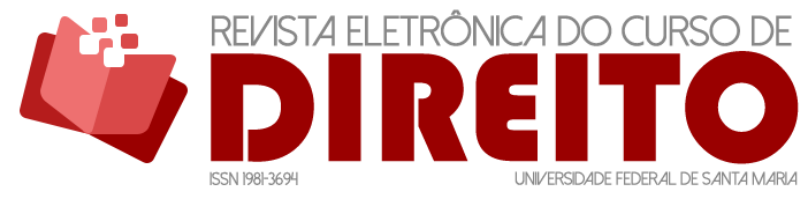

INFLUÊNCIA DA COMMON LAW NA IMPLANTAÇÃO DOS PRECEDENTES JUDICIAIS VINCULANTES NO BRASIL NA ERA DA SOCIEDADE DA INFORMAÇÃO

MARCELO GUERRA MARTINS GUSTAVO FILIPE BARBOSA GARCIA AUGUSTO TAVARES ROSA MARCACINI

inferiores. Da mesma forma que seria muito difícil para o juiz da civil law decidir contra a letra da lei (salvo hipóteses de inconstitucionalidade) o mesmo embaraço encontra o juiz da common law para contrariar um precedente, visto como verdadeira norma vinculante.

Noutra ponta, nos sistemas em que a civil law predomina, como é o caso do Brasil, o juiz sempre foi encarado como alguém que não cria o direito, mas, ao contrário, somente o aplica. Trata-se, de certa forma, da já citada concepção francesa do juiz como mera bouche de la loi. Nesse cenário, apenas as disposições constitucionais e legais seriam capazes de obrigar os juízes e não as interpretações dadas a essas normas pelos Tribunais.

Mesmo que essa concepção, em teoria, reverencie o princípio democrático, na medida em que os juízes sentem-se obrigados a respeitar tão somente os preceitos emanados pelos representantes do povo, na prática, conforme aqui já foi tratado, isso acabou redundando num comportamento judicial de baixa previsibilidade, pouca ou nenhuma estabilidade e, sobretudo, flagrantemente contrário à isonomia.

Desse modo, o "direito brasileiro, ao admitir o controle difuso de constitucionalidade típico do direito estadunidense -, tornou-se incompatível com a sua prática jurídica, em que os tribunais ordinários não se curvam à autoridade dos precedentes constitucionais" 45 .

Portanto, chega a ser intuitivo perceber a necessidade de existirem órgãos decisórios superiores que fechem o sistema, isso é, que especifiquem os significados possíveis e aceitáveis às disposições constitucionais e legais, principalmente aquelas de maior generalidade. No Brasil, isso começou a ser implantado de modo mais palpável apenas por ocasião do advento da Emenda Constitucional $n^{\circ} 45$, de 30 de dezembro de 2004. Entretanto, um longo caminho foi percorrido anteriormente.

\section{LONGO CAMINHO RUMO À UNIFORMIZAÇÃO DA JURISPRUDÊNCIA NO}

\section{BRASIL}

\subsection{Antecedentes remotos da uniformização de jurisprudência no direito luso- brasileiro}

O Direito, ciência humana que é, inexato por sua natureza, sempre conviveu com dificuldades interpretativas no preenchimento de lacunas, na adequação de suas normas ao caso

${ }^{45}$ MARINONI, Luiz Guilherme, op. cit., p. 57. 
ISSN 1981-3694

(DOI): $10.5902 / 1981369431054$

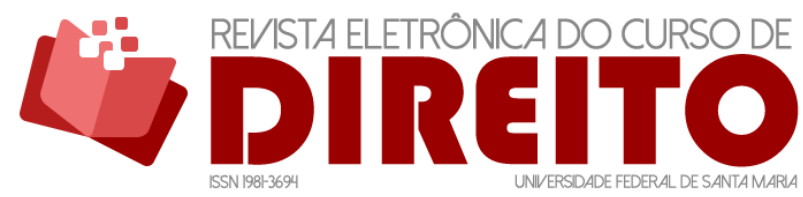

INFLUÊNCIA DA COMMON LAW NA IMPLANTAÇÃO DOS PRECEDENTES JUDICIAIS VINCULANTES NO BRASIL NA ERA DA SOCIEDADE DA INFORMAÇÃO

MARCELO GUERRA MARTINS GUSTAVO FILIPE BARBOSA GARCIA AUGUSTO TAVARES ROSA MARCACINI

concreto, ou outras dificuldades na sua aplicação que produzem decisões diferentes para situações semelhantes.

Com a fragmentação do direito romano após a derrocada do Império, predominou na península ibérica um ordenamento de direito costumeiro, formado pela conjunção de regras consuetudinárias gerais e locais e em precedentes judiciais conhecidos por façanha ou fazaña, transmitidos por memória oral, mas também compilados em coletâneas de "casos julgados notáveis e duvidosos, cuja força vinculante decorria da autoridade reconhecida a quem as proferia e aprovava" ${ }^{46}$. À coleção desses preceitos costumeiros e precedentes judiciais era atribuído o nome de forais, em Portugal, ou fueros, em Espanha ${ }^{47}$.

Com a crescente afirmação do poder central, após a formação do estado português, e a correlata edição de leis pelo monarca, observou-se a superposição destas aos costumes locais, às antigas normas romanas ou aos cânones da Igreja. Critérios interpretativos são fixados nas Ordenações Afonsinas, estabelecendo que somente em caso de lacuna das leis do reino seja aplicado, subsidiariamente, o direito romano, se a solução por ele prescrita não importasse em cometimento de pecado, caso em que se aplicaria o direito canônico. E se o litígio não pudesse ser solucionado pelas leis do reino, seus costumes ou estilos, nem pelo direito romano ou canônico, determinava-se a observância das glosas de Acursio ou os comentários de Bartolo. ${ }^{48} \mathrm{E}$ em momento histórico seguinte, como anota Mario Júlio de Almeida Costa:

0 problema da interpretação da lei com sentido universalmente vinculativo para futuro foi disciplinado por um diploma da segunda década do século XVI. Os seus dispositivos incluíram-se, depois, nas Ordenações Manuelinas e passaram às Ordenações Filipinas. Determinou-se que, surgindo dúvidas aos desembargadores da Casa da Suplicação sobre o entendimento de algum preceito, tais dúvidas deveriam ser levadas ao regedor do mesmo tribunal. Este convocaria os desembargadores que entendesse e, com eles, fixava a interpretação que se considerasse mais adequada. 0 regedor da Casa da Suplicação poderia, aliás, submeter a dúvida a resolução do monarca, se subsistissem dificuldades interpretativas. As soluções definidas ficavam registadas no Livro dos Assentos e tinham força imperativa para futuros casos idênticos. Surgem, deste modo, os assentos da Casa da Suplicação como jurisprudência obrigatória. ${ }^{49}$

Como afirmado por Frederico Marques, "as fazañas y albedrios do Direito ibérico são os antecedentes, em nosso Direito, dessa preocupação unificadora em relação aos julgados. Vieram

46 TUCCI, Josér Rogério Cruz e; AZEVEDO, Luiz Carlos de. Lições de história do processo civil lusitano. São Paulo: Revista dos Tribunais, 2009, p. 160.

47 Ibidem.

48 PORTUGAL. Ordenações Afonsinas. L. II, T. 9.

${ }^{49}$ COSTA, Mário Júlio de Almeida. História do direito português. Coimbra: Almedina, 2002, pp. 300-301. 
ISSN 1981-3694

(DOI): $10.5902 / 1981369431054$

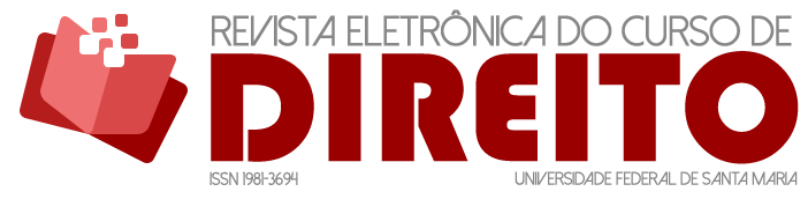

INFLUÊNCIA DA COMMON LAW NA IMPLANTAÇÃO DOS PRECEDENTES JUDICIAIS VINCULANTES NO BRASIL NA ERA DA SOCIEDADE DA INFORMAÇÃO

MARCELO GUERRA MARTINS GUSTAVO FILIPE BARBOSA GARCIA AUGUSTO TAVARES ROSA MARCACINI

depois os assentos da Casa de Suplicação [...]"50. E, embora a Constituição brasileira de 1824 não previsse a existência de meios para uniformização da jurisprudência, uma lei de 1875 atribuía ao Supremo Tribunal de Justiça, então órgão máximo do Poder Judiciário ao tempo do Império, a função de "tomar assentos para inteligência das leis civis, comerciais e criminais, quando na execução deles ocorrerem dúvidas manifestadas por julgamentos divergentes havidos no mesmo Tribunal, Relações e Juízos de primeira instância nas causas que cabem na sua alçada"51.

Todavia, não se sabe ao certo, dada a ausência de dados estatísticos específicos, se esses antigos mandamentos foram efetivamente providos de eficácia, chagando a atingir o desiderato de uniformizar os entendimentos judiciais durante tempo razoavelmente longo.

\subsection{Legislações estaduais e o Código de Processo Civil de 1939}

Um antecedente dos atuais instrumentos de uniformização jurisprudencial no Brasil foi o chamado recurso de revista, previsto no art. 853 do Código de Processo Civil de 1939 (Decretolei $n^{\circ} 1.608$, de 18 de setembro de 1939). Deflagrado pela parte perdedora, tinha cabimento quando houvesse divergência, na matéria de direito, entre duas ou mais Câmaras ou Turmas de um mesmo Tribunal. O tema, então, era afetado a um colegiado maior (Plenário, Câmaras ou Turmas reunidas, etc.) para fins de se decidir qual interpretação deveria prevalecer no caso.

A interpretação "correta” da lei também poderia ser buscada antes do julgamento de determinado caso. Desse modo, nos termos do art. 861 do CPC de 1939, quaisquer dos juízes do Tribunal (e não as partes do processo) poderiam provocar o pronunciamento prévio do colegiado maior quando houvesse (ou pudesse haver) divergência de interpretação a respeito de determinada questão jurídica. Tratava-se do denominado de prejulgado ${ }^{52}$ Tal instituto que, segundo Jorge Americano, não tinha natureza de recurso mas de uma preliminar no julgamento de recursos, ${ }^{53}$ foi originalmente criado pelo Decreto n. $16.273 / 1923$, que reorganizou a Justiça do Distrito Federal, encontrando-se também previsto no Código Estadual paulista ${ }^{54}$.

\footnotetext{
${ }^{50}$ MARQUES, José Frederico. Instituições de direito processual civil, vol. IV. Rio de Janeiro: Forense, 1969, p. 102.

51 Ibidem, p. 103.

52 COSTA, Alfredo de Araújo Lopes da. Manual elementar de direito processual civil. Rio de Janeiro: Forense, 1956, p. 184.

${ }^{53}$ AMERICANO, Jorge. Comentários ao código de processo civil do Brasil, 4. vol. São Paulo: Saraiva, 1960, p. 79.

54 SÃO PAULO. Código do processo civil e commercial do Estado de São Paulo, Lei n. 2.421, de 14 de janeiro de 1930, art. 1.126.
} 
ISSN 1981-3694

(DOI): $10.5902 / 1981369431054$

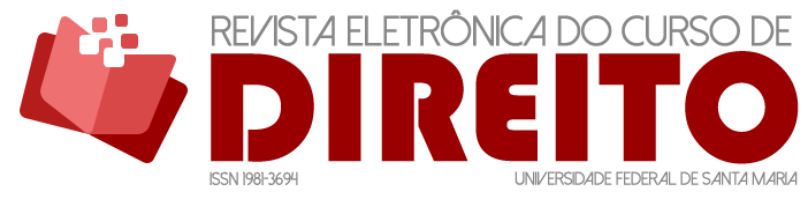

INFLUÊNCIA DA COMMON LAW NA IMPLANTAÇÃO DOS PRECEDENTES JUDICIAIS VINCULANTES NO BRASIL NA ERA DA SOCIEDADE DA INFORMAÇÃO

MARCELO GUERRA MARTINS GUSTAVO FILIPE BARBOSA GARCIA AUGUSTO TAVARES ROSA MARCACINI

Todavia, quanto à criação de precedentes com força suficiente para promover a uniformização da jurisprudência, esses incidentes foram pouco eficazes ${ }^{55}$.

Primeiro, havia a questão burocrática em si. É que o julgamento do caso passaria a depender de uma fase adicional relativamente complexa, ou seja, o prévio pronunciamento de um colegiado maior, o que requeria a participação de vários outros magistrados da Corte usualmente já assoberbados com os próprios casos.

Segundo, como a lei não esclarecia o limite da aplicação do pronunciamento do colegiado maior, passou-se a entender que seus efeitos restringiam-se apenas aos casos que haviam dado origem à revista ou ao prejulgado, não vinculando, portanto, eventuais casos futuros $^{56}$. Desse modo, a mesma divergência de entendimento poderia se repetir e, pior, nada impedia que o colegiado maior decidisse de forma diferente do que anteriormente havia dito, o que não resolvia o problema da segurança jurídica. Dessa maneira, em termos de custo/benefício, não era compensatório.

Terceiro, não se pode descartar que a pouca utilização desses incidentes tenha como possível causa acessória a eventual pouca disposição dos magistrados de abrirem mão de suas convicções pessoais em prol de um pronunciamento de um colegiado maior cujo conteúdo poderia não lhes agradar. Em suma, talvez não estivessem os julgadores dispostos a abrir mão do poder de interpretar o direito segundo suas próprias convicções de momento.

\subsection{O Código de Processo Civil de 1973}

A situação perdurou com o Código de 1973 (Lei n 5.925, de 11 de janeiro de 1973), ao menos em seus primórdios. Foram inicialmente previstos, no âmbito dos Tribunais, o incidente de uniformização de jurisprudência e o de declaração de inconstitucionalidade.

\footnotetext{
55 Nos derradeiros anos de vigência do Código de 1939, José Frederico Marques teceu os seguintes comentários sobre o prejulgado: "Ao que parece, não tem sido ele muito empregado, embora devessem os juízes valer-se, mais a miúdo, de tal remédio, para evitar as procrastinações que o recurso de revista sempre traz. Além do mais, muito ganhariam, não só a celeridade da resolução das causas, como, também, a segurança e uniformidade na aplicação da lei, se o uso do prejulgado estivesse mais generalizado. Sua utilidade e eficiência seria muito maior que as do recurso de revista. Infelizmente, porém, dele se não tem lançado mão, salvo um ou outro caso esporádico em que se fez aplicação do art. 861 do Cód. de Proc. Civil" (ob. cit., p.244).

56 Isso se repetiu sob a égide do CPC de 1973 em relação aos incidentes de uniformização de jurisprudência e de declaração de inconstitucionalidade. Nesse sentido, por exemplo, foi a decisão proferida, em 01/07/2008, pela Segunda Turma do Tribunal Regional Federal da $5^{\text {a }}$ Região, nos autos n. 2000.05.00.047509-0.
} 


\subsubsection{Incidente de uniformização de jurisprudência e de arguição de inconstitucionalidade}

O instituto do prejulgado, previsto em um único artigo, no Código de 1939, e mal localizado no mesmo capítulo destinado ao recurso de revista, daria lugar ao incidente de uniformização de jurisprudência, no Código de 1973, nitidamente destacado dos recursos previstos naquela lei, dele se ocupando os seus arts. 476 a 479.

Conforme o art. 476 do CPC de 1973, antes de proferir seu voto perante a Câmara ou Turma, poderia o magistrado solicitar que o Tribunal solucionasse divergência existente na interpretação de determinada questão de direito pelas demais Câmaras ou Turmas. A resposta deveria ser dada pelo voto da maioria absoluta dos membros da Corte (art. 478), devendo ser objeto de súmula que se constituiria em precedente na uniformização da jurisprudência (art. 479).

Por sua vez, nos termos do art. 480 do CPC de 1973, arguida a inconstitucionalidade de lei ou de ato normativo do poder público, o relator, ouvido o Ministério Público, deveria submeter a questão à respectiva Câmara ou Turma. Rejeitada a alegação, o julgamento prosseguia, mas se acolhida fosse, o colegiado maior deveria se manifestar a respeito para confirmar ou negar a arguição em jogo (art. 481).

$\mathrm{Na}$ prática, esses incidentes tiveram pouca relevância em termos de criação de precedentes uniformizadores de jurisprudência, e isso ocorreu provavelmente pelos mesmos motivos que implicaram na pouca expressividade do recurso de revista e do prejulgado do CPC de 1939 (burocracia do julgamento, custo/benefício não compensatório e baixa disposição à delegação do poder decisório a outro órgão).

\subsubsection{Lei 9.756/98 e o julgamento monocrático nos Tribunais}

Posteriormente, já no final do século passado, com objetivo de facilitar a fundamentação das decisões, a legislação passou a prever um tipo de incentivo para que os magistrados adotassem o preceituado em súmulas ou posicionamentos dominantes nos Tribunais. Nesses casos, bastava ao julgador invocar certa súmula ou compilar os principais precedentes a respeito e lavrar o decisum sem maiores digressões a respeito, o que, de certa forma, facilitava o trabalho. 
ISSN 1981-3694

(DOI): $10.5902 / 1981369431054$

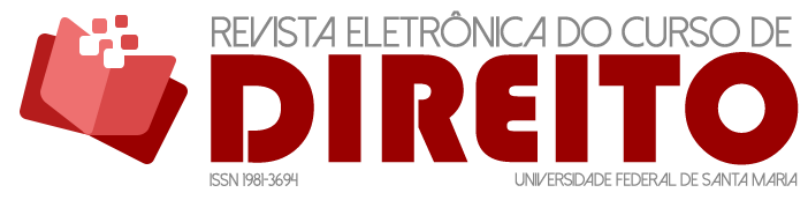

INFLUÊNCIA DA COMMON LAW NA IMPLANTAÇÃO DOS PRECEDENTES JUDICIAIS VINCULANTES NO BRASIL NA ERA DA SOCIEDADE DA INFORMAÇÃO

MARCELO GUeRRa MARTINS GUSTAVO FILIPE BARBOSA GARCIA AUGUSTO TAVARES ROSA MARCACINI

Nessa linha, com a vinda da Lei 9.756/1998, que modificou a redação do art. 557 do CPC de 1973, nas Cortes de Segunda Instância, o relator, por decisão monocrática, podia negar seguimento a recurso em confronto com súmula ou com jurisprudência dominante do respectivo Tribunal, do Supremo Tribunal Federal, ou de Tribunal Superior.

A recíproca também era possível, isso é, se a decisão recorrida estivesse em manifesto confronto com súmula ou jurisprudência das citadas Cortes, o relator poderia, em decisão individual, desde logo, dar provimento ao recurso (parágrafo único do art. 557 do CPC de 1973).

Sistemática quase idêntica também foi aplicada para os recursos extraordinários (Supremo Tribunal Federal) e especiais (Superior Tribunal de Justiça). Em suma, podiam os ministros relatores, por decisão monocrática, darem ou negarem provimento aos recursos segundo a conformidade da decisão atacada com súmula ou jurisprudência dominante da própria Corte (art. 544 do CPC/73, com redação dada pelas Leis 9.756/1998 e 12.322/2010).

Contra as decisões monocráticas prolatadas nessa sistemática cabia agravo, o que acabava levando a discussão do tema para a respectiva Câmara ou Turma. Todavia, quando realmente a decisão encontrasse esteio em súmula ou jurisprudência dominante, a tendência era sempre a sua manutenção.

\subsection{Emenda 45/2004 e as Leis 11.418/2006 e 11.672/2008: súmula vinculante, repercussão geral e recurso representativo de controvérsia}

A Emenda Constitucional 45, de 30 de dezembro de 2004 (conhecida como Emenda da Reforma do Judiciário) promoveu grande evolução no campo da uniformização da jurisprudência. Foram criados novos instrumentos voltados a dar maior efetividade aos precedentes jurisprudenciais: a súmula vinculante e a repercussão geral nos recursos extraordinários para o STF.

Nos termos do art. 103-A da Constituição Federal de 1988 (inserido pela EC 45/2004), o Supremo Tribunal Federal, após reiteradas decisões sobre matéria constitucional, por decisão de $2 / 3$ de seus membros, passou a poder aprovar súmula com efeito vinculante em relação aos demais órgãos do Poder Judiciário e da administração pública direta e indireta, nas esferas federal, estadual e municipal.

A Emenda Constitucional 45/2004 também inovou o regime dos recursos extraordinários, passando a constar como pressuposto de admissibilidade a presença de repercussão geral. A 
ISSN 1981-3694

(DOI): $10.5902 / 1981369431054$

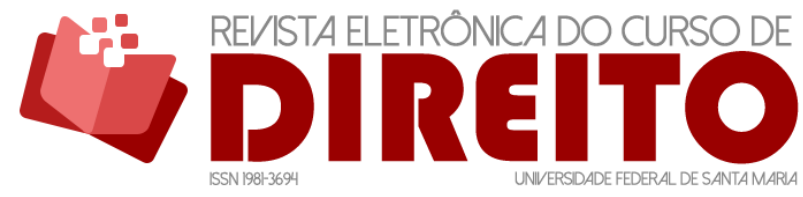

INFLUÊNCIA DA COMMON LAW NA IMPLANTAÇÃO DOS PRECEDENTES JUDICIAIS VINCULANTES NO BRASIL NA ERA DA SOCIEDADE DA INFORMAÇÃO

MARCELO GUERRA MARTINS GUSTAVO FILIPE BARBOSA GARCIA AUGUSTO TAVARES ROSA MARCACINI

regulação veio em 2006, com a Lei 11.418 que inseriu no CPC de 1973 os arts. 543-A e 543-B, estipulando como portadores de repercussão geral os recursos em que houvesse questões relevantes do ponto de vista econômico, político, social ou jurídico e que ultrapassassem os interesses subjetivos da causa.

Pela nova sistemática, mantida, em essência, pelo Código de 2015, passou a ser competência exclusiva do STF reconhecer a presença (ou não) da repercussão geral, escolhendo, para tanto, tão somente um recurso dentre outros tantos que tratassem da mesma matéria. Nesse tópico, nota-se forte semelhança com a figura do certionary da Suprema Corte dos Estados Unidos da América que tem o poder de escolher os recursos que serão levados a julgamento, cuja sistemática encontra-se detalhada no regimento normativo daquela Corte ${ }^{57}$.

Assim, reconhecida a repercussão em determinado recurso, apenas esse recurso, tido como paradigma, teria o mérito futuramente decidido pelo STF.

Enquanto esse julgamento não acontecia, ficavam sobrestados todos os demais recursos extraordinários que tratassem do mesmo tema e que ainda aguardavam decisão de admissibilidade pela Presidência (ou Vice-Presidência) dos Tribunais de origem, incluindo-se as Turmas de Uniformização ou Turmas Recursais ${ }^{58}$. Os recursos que, eventualmente, já tivessem subido ao STF, deveriam ser devolvidos às Cortes de origem para ficarem sobrestados.

Porém, se o STF entendesse que determinado tema não era dotado de repercussão geral, a decisão valia para todos os demais extraordinários com matéria idêntica, que deveriam ser indeferidos liminarmente pelo Presidente (ou Vice) da Corte local.

Julgado o mérito do recurso pelo STF, os casos sobrestados cujos acórdãos estivessem em confronto como decidido pelo STF eram submetidos a novo julgamento pela Câmara ou Turma, sendo possível a retratação, de modo a harmonizar o entendimento do órgão julgador com a posição adotada pelo STF. Caso a decisão recorrida já se encontrasse no mesmo sentido do decidido pelo STF, o recurso extraordinário era declarado prejudicado ( $\S 3^{\circ}$ do art. 543-B do CPC de 1973), não se promovendo novo julgamento. Todavia, a retratação não era obrigatória. Desse modo, segundo o $\S 4^{\circ}$ do art. 543-B do CPC de 1973, mantida a decisão e admitido o recurso extraordinário, poderia o STF, nos termos do Regimento Interno, cassar ou reformar, liminarmente, o acórdão contrário à orientação firmada.

57 Rules of the Supreme Court of the United States (rules 5 a 16).

${ }^{58}$ Conforme o regime do CPC/73, tanto o recurso extraordinário (para o STF) quanto o especial (para o STJ) eram protocolados no Tribunal de origem, junto à Presidência ou Vice Presidência (conforme a organização judiciária local) que admitiam (ou não) os recursos, dependendo da presença dos pressupostos legais de admissibilidade. Em linhas gerais, esse modus operandi foi mantido no CPC de 2015. 
ISSN 1981-3694

(DOI): $10.5902 / 1981369431054$

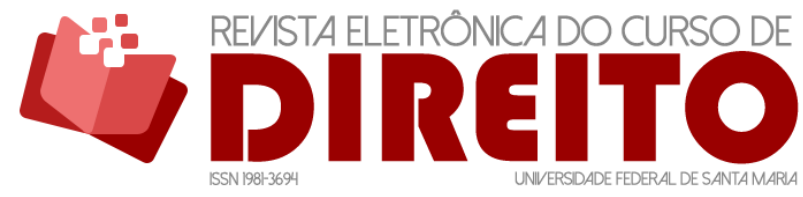

INFLUÊNCIA DA COMMON LAW NA IMPLANTAÇÃO DOS PRECEDENTES JUDICIAIS VINCULANTES NO BRASIL NA ERA DA SOCIEDADE DA INFORMAÇÃO

MARCELO GUERRA MARTINS GUSTAVO FILIPE BARBOSA GARCIA AUGUSTO TAVARES ROSA MARCACINI

Não restam dúvidas, portanto, que o regime da repercussão geral foi instituído com o objetivo primordial de "uniformizar a interpretação constitucional sem exigir que a Corte decida múltiplos casos idênticos sobre a mesma questão constitucional" 59 .

Por fim, por meio da Lei 11.672/2008, que introduziu o art. 543-C no CPC de 1973, foi inserido no sistema, no âmbito do Superior Tribunal de Justiça, o recurso representativo de controvérsia, cuja sistemática se assemelhava àquela da repercussão geral do STF.

Desse modo, escolhido pelo STJ um recurso especial como representativo de controvérsia, todos os demais que tratassem do mesmo tema ficavam sobrestados nos Tribunais de origem até que o mérito do recurso paradigma fosse decidido pelo STJ. Quando isso ocorria, todos aqueles recursos cujo acórdão recorrido coincidisse com a orientação adotada pelo STJ tinham seguimento denegado.

Noutro giro, os casos cuja decisão atacada era divergente do que decidira o STJ eram submetidos ao juízo de retratação pela Câmara ou Turma. Se, eventualmente, fosse mantida a decisão divergente pelo Tribunal de origem, era realizado o exame de admissibilidade do recurso especial ${ }^{60}$.

\subsection{Código de Processo Civil de 2015}

O CPC de 2015 (Lei 13.105, de 16 de março de 2015) não deixa dúvida quanto ao papel dos Tribunais em relação à jurisprudência. Com efeito, segundo seu art. 926: "Os tribunais devem uniformizar sua jurisprudência e mantê-la estável, íntegra e coerente”. 0 novo Código ampliou e aprimorou algumas ferramentas já previstas no CPC de 1973, bem como trouxe novos incidentes processuais com o objetivo de tornar realidade o preceituado no art. $926^{61}$.

\footnotetext{
59 LEAL, Saul Tourinho. A repercussão geral em matéria tributária segundo o Supremo Tribunal Federal. Revista Dialética de Direito Tributário, n. 165, jun. de 2009, p. 110.

60 Diversamente do que ocorria em relação à repercussão geral do STF, se a decisão fosse mantida pela Câmara ou Turma, não havia previsão para que o STJ cassasse ou reformasse liminarmente o acórdão contrário à orientação firmada. Era necessário proceder normalmente ao julgamento do recurso especial, cujo resultado, obviamente, seria a reforma da decisão rebelde.

${ }^{61} \mathrm{O}$ sistema das súmulas vinculantes do STF, cuja regulamentação provém da própria Constituição e do Regimento Interno da Corte Suprema, permaneceu inalterado.
} 


\subsubsection{Julgamento de improcedência sem a citação do réu}

Primeiramente, nota-se que o antigo art. 285-A do CPC de $1973^{62}$ foi amplificado pelo art. 332 do CPC de 2015. Desse modo, nos casos que dispensem a fase instrutória (ou seja, quando a prova for exclusivamente documental), o juiz, independentemente da citação do réu, julgará liminarmente improcedente o pedido que contrariar: enunciado de súmula do STF ou do STJ (inciso I); acórdão proferido pelo STF ou pelo STJ em julgamento de recursos repetitivos ${ }^{63}$ (inciso II); entendimento firmado em incidente de resolução de demandas repetitivas ou de assunção de competência (inciso III); enunciado de súmula de Tribunal de Justiça sobre direito local (inciso IV).

$0 \S 1^{\circ}$ do art. 332 em pauta igualmente estabelece que a improcedência também poderá ser decretada nos mesmos moldes, ou seja, sem a citação do réu, se o juiz verificar, de plano, a ocorrência de decadência ou de prescrição ${ }^{64}$.

\subsubsection{Introdução do stare decisis, distinguishing e overruling}

Antes de prosseguir, é oportuno advertir que a análise e a comparação de institutos jurídicos provenientes de outros sistemas, como no presente caso, deve ser precedida da devida cautela de modo a evitar conclusões simplistas ou dissociadas da realidade, e, por conseguinte, de pouca serventia em termos científicos. 0 cuidado se impõe porque, segundo Pierre Legrand ${ }^{65}$, "tudo o que o intérprete pode realizar é propor uma transposição do direito estrangeiro para a

\footnotetext{
62 Apenas para recordar, o art. 285-A do CPC/73 permitia que quando a matéria controvertida fosse unicamente de direito e no juízo já houvesse sido proferida sentença de total improcedência em outros casos idênticos, poderia ser dispensada a citação e desde logo proferida a sentença, com reprodução do teor da anteriormente prolatada.

${ }^{63}$ Segundo o art. 928 do CPC de 2015, considera-se julgamento de casos repetitivos a decisão proferida em: "I - incidente de resolução de demandas repetitivas; II - recursos especial e extraordinário repetitivos. Parágrafo único. 0 julgamento de casos repetitivos tem por objeto questão de direito material ou processual".

${ }^{64} \mathrm{~A}$ adoção desse sistema revela, no mínimo, dois benefícios adicionais: primeiro, a celeridade processual, visto que a sentença é prolatada desde logo, e, segundo, ao menos num primeiro momento, evita que o réu dispenda recursos com a contratação de advogados para a efetivação de sua defesa. Contudo, em havendo apelação por parte do autor, o juiz, salvo se se retratar da sentença, determinará o prosseguimento do processo, com a citação do réu para apresentar contrarrazões, no prazo de 15 (quinze) dias ( $\$ 4^{\circ}$ do art. 332 do atual CPC).

65 LEGRAND, Pierre. Negative comparative law. Journal of Comparative Law, vol. 10, n. 2, 2015, p. 412. 0 texto original é o seguinte: "All that the interpreter can ever accomplish is to propound a transposition of foreign law into 'his' language, into 'his' thought (as if language and thought belonged)".
} 
ISSN 1981-3694

(DOI): $10.5902 / 1981369431054$

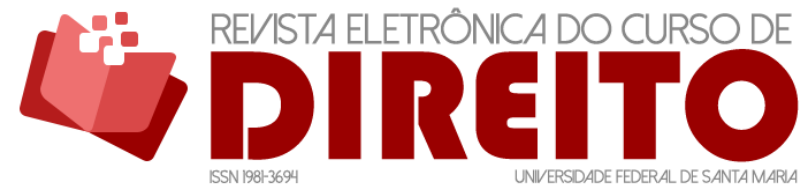

INFLUÊNCIA DA COMMON LAW NA IMPLANTAÇÃO DOS PRECEDENTES JUDICIAIS VINCULANTES NO BRASIL NA ERA DA SOCIEDADE DA INFORMAÇÃO

MARCELO GUERRA MARTINS GUSTAVO FILIPE BARBOSA GARCIA AUGUSTO TAVARES ROSA MARCACINI

'sua' linguagem, para o 'seu' pensamento (como se a linguagem e o pensamento a ele pertencessem)".

Desse modo, não se pode ultimar uma mera tradução dos vocábulos em jogo, sendo de rigor levar em conta a conjuntura jurídica, social e até econômica em que se situa o direito estrangeiro, na linha da proposição engendrada por Günter Frankenberg dos necessários "distanciamento" e a "diferenciação". Segundo o autor, é preciso "impedir que o comparista confunda suas ideias (ocidentais) e conceitos com os critérios de uma verdade universal e lógica" ${ }^{66}$. Em adição, a análise comparativa não pode se resumir à dogmática dos preceitos em cena. É que, na lição de Deo Campos Dutra:

A compreensão dogmática é parte importante e intrínseca do trabalho do comparista, mas nem de longe é a última operação que deve ser feita no processo de comparação jurídica. Ela precisa de ser feita com atenção, pesquisas aprofundadas e rígida análise dos textos primários e secundários que estão sendo comparados. ${ }^{67}$

Nesse passo, sob o pálio das advertências e perspectivas acima delineadas, prosseguimos trazendo à baila o CPC de 2015 que, em nosso juízo, reflete a intenção do legislador de aproximar o sistema brasileiro da commom law, com a introdução de três ferramentas típicas do direito anglo-saxão: stare decisis, distinguishing e overruling. A regra do stare decisis (ou precedente) “dispõe que a decisão do tribunal superior vincula o tribunal inferior, e que também não pode desobedecer ao próprio precedente, a não ser por uma razão extraordinária"68.

Nesse campo específico, segundo decidiu a Suprema Corte dos Estados Unidos, no caso Payene v. Tennessee (501 U.S. 808, 827), o “o Stare decisis é a maneira mais conveniente porque ele promove o desenvolvimento equânime, previsível e consistente dos princípios

\footnotetext{
66 FRANKENBERG, Günter. Critical comparisons: re-thinking comparative law. Harvard International Law Journal, vol. 26, n. 2, 1985, p. 414. O texto original é o seguinte: "prevent the observer-compararist from confusing the present content of (Western) ideas and concepts with the criteria of a universal truth and logic".

${ }^{67}$ DUTRA, Deo de Campos. Da ortodoxia à crítica: teorias da comparação jurídica. Revista Brasileira de Direito, vol. 14, n. 1, jan./abr. 2018, p. 207.

${ }^{68}$ MELLO, Maria Chaves de. Dicionário jurídico português inglês - inglês português. 10. ed. São Paulo: Método, 2012, p. 1.039.
} 
ISSN 1981-3694

(DOI): $10.5902 / 1981369431054$

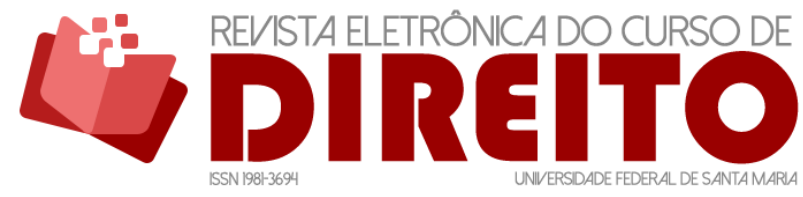

INFLUÊNCIA DA COMMON LAW NA IMPLANTACCÃO DOS PRECEDENTES JUDICIAIS VINCULANTES NO BRASIL NA ERA DA SOCIEDADE DA INFORMAÇÃO

MARCELO GUERRA MARTINS GuSTAVO FILIPE BARBOSA GARCIA AUGUSTO TAVARES ROSA MARCACINI

jurídicos, favorece a confiança legítima na justiça e contribui para a integridade, real e percebida, do processo judicial”69.

0 distinguishing ${ }^{70}$ e o overrruling $^{71}$ representam a não aplicação de determinado precedente a um caso sub judice. 0 primeiro, em vista de diferenças suficientes para afastar a identidade entre os casos e o segundo quando houver superação do precedente pelo Tribunal. Em ambas as hipóteses, o juiz deverá demonstrar os motivos do não encaixe do precedente.

$\mathrm{O}$ art. 489, § $1^{\circ}, \mathrm{VI}$, do CPC de 2015 passou a considerar não fundamentada qualquer decisão judicial, seja ela interlocutória, sentença ou acórdão, que deixar de seguir enunciado de súmula, jurisprudência ou precedente invocado pela parte, sem demonstrar a existência de distinção no caso em julgamento ou a superação do entendimento.

Considerando que a falta de fundamentação implica na nulidade de qualquer decisão judicial (salvo aquelas de mero expediente), em outras palavras o preceito em tela tem por objetivo induzir os magistrados a seguirem o stare decisis, incorporado no direito pátrio por meio das súmulas, da jurisprudência ou do precedente invocado pela parte.

As únicas ressalvas feitas pela lei são as hipóteses de o caso sub judice ser distinto (distinguishing) ou de o entendimento encontrar-se superado (overruling), devendo, no entanto, o juiz fundamentar a ocorrência dessas hipóteses.

Tratando-se de sistemática recém-nascida, seu sentido e extensão ainda carecem de melhor fixação. Há algumas perguntas ainda merecem resposta, tais como: considerando que a lei não fala em súmula vinculante, seriam suficientes os enunciados "comuns" do STF, do STJ ou mesmo do Tribunal ao qual o juiz estiver vinculado? Qual a extensão a ser dada ao termo jurisprudência? Bastaria um número relevante de casos decididos num certo sentido? Jurisprudência do STF, do STJ, da Corte local? E o termo precedente? Seriam as decisões tomadas em casos nos quais a lei já confere efeito obrigatório (recursos extraordinários, especiais, incidentes de assunção de competência e de resolução de demandas repetitivas)?

Porém, não se pode ignorar que o preceito em foco é complementado pelo art. 927 do CPC que, em síntese, determina ser obrigatório aos juízes e Tribunais observarem: as decisões do Supremo Tribunal Federal em controle concentrado de constitucionalidade (inciso I); os enunciados de súmula vinculante (inciso II); os acórdãos em incidente de assunção de

69 O texto original é o seguinte: "Stare decisis is the preferred course, because it promotes the evenhanded, predictable, and consistent development of legal principles, fosters reliance on judicial decisions, and contributes to the actual and perceived integrity of the judicial process".

${ }_{70}$ MELLO, Maria Chaves de, op. cit., p. 755.

71 Ibidem, p. 951. 
ISSN 1981-3694

(DOI): $10.5902 / 1981369431054$

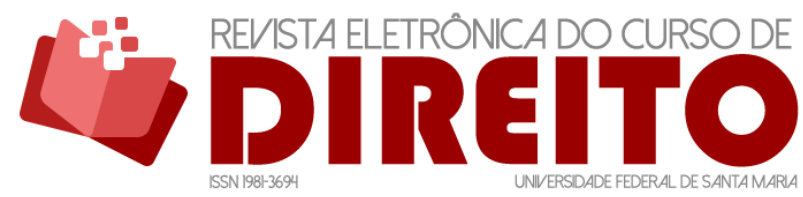

INFLUÊNCIA DA COMMON LAW NA IMPLANTAÇÃO DOS PRECEDENTES JUDICIAIS VINCULANTES NO BRASIL NA ERA DA SOCIEDADE DA INFORMAÇÃO

MARCELO GUERRA MARTINS GUSTAVO FILIPE BARBOSA GARCIA AUGUSTO TAVARES ROSA MARCACINI

competência ou de resolução de demandas repetitivas e em julgamento de recursos extraordinário e especial repetitivos (inciso III); os enunciados das súmulas do Supremo Tribunal Federal em matéria constitucional e do Superior Tribunal de Justiça em matéria infraconstitucional (inciso IV); a orientação do plenário ou do órgão especial aos quais estiverem vinculados (inciso V).

Nesse passo, parece fora de dúvida que o legislador do CPC procurou introduzir no sistema judicial nacional a sistemática dos precedentes vinculantes, na linha do que vem sendo praticado em países de common law. A diferença é que, como já visto, na common law nunca se se cogitou expressamente da necessidade de uma norma escrita como a lei (statute law) para tal desiderato.

\subsubsection{Julgamento monocrático nos Tribunais}

Pelo CPC de 2015, nos Tribunais de Segunda Instância permanece a possibilidade de os relatores decidirem monocraticamente os recursos. Assim, é possível, desde logo, negar provimento a recurso cujas razões sejam contrárias a: súmula do STF, do STJ ou do próprio Tribunal; acórdão proferido pelo STF ou pelo STJ em julgamento de recursos repetitivos; entendimento firmado em incidente de resolução de demandas repetitivas ou de assunção de competência (art. 932, IV do CPC de 2015).

Por outro lado, é também possível ao relator dar provimento ao recurso que ataque decisão contrária aos elementos acima citados. Todavia, essa hipótese deve ocorrer apenas depois de facultada a apresentação das contrarrazões pela parte adversa (art. 932, V, do CPC de 2015).

\subsubsection{Incidente de assunção de competência}

Trata-se de uma novidade do CPC de 2015 (arts. 947 e seguintes). É cabível na hipótese de um recurso ${ }^{72}$ envolver relevante questão de direito, com grande repercussão social, mas sem repetição em múltiplos processos, ou seja, a tese jurídica envolvida não se reproduz em tantos outros casos. É o que pode ocorrer, por exemplo, nas ações coletivas (as ações civis públicas e os mandados de segurança coletivos).

Nessas situações, o recurso é remetido a um colegiado maior, que julgará o incidente apenas se reconhecer a presença de interesse público a justificar sua atuação. Conforme o $\$ 3^{\circ}$

720 mesmo é aplicável à remessa necessária ou processo de competência originária. 
ISSN 1981-3694

(DOI): $10.5902 / 1981369431054$

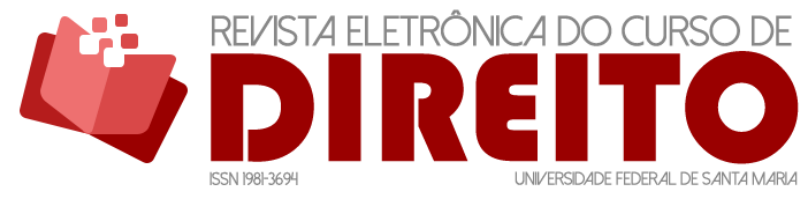

INFLUÊNCIA DA COMMON LAW NA IMPLANTAÇÃO DOS PRECEDENTES JUDICIAIS VINCULANTES NO BRASIL NA ERA DA SOCIEDADE DA INFORMAÇÃO

MARCELO GUERRA MARTINS GUSTAVO FILIPE BARBOSA GARCIA AUGUSTO TAVARES ROSA MARCACINI

do art. 947: “O acórdão proferido em assunção de competência vinculará todos os juízes e órgãos fracionários, exceto se houver revisão de tese" (aplicação da regra do stare decisis e do overruling).

Não há, dessa forma, retorno dos autos à Câmara ou Turma original para prosseguir o julgamento, como ocorria nos incidentes de uniformização de jurisprudência e arguição de inconstitucionalidade do CPC de 1973. É o colegiado maior que decide o recurso por inteiro. Por isso, não tem mais como prevalecer o antigo entendimento de que as soluções do colegiado maior vinculam apenas a decisão a ser proferida no caso que originou o incidente ${ }^{73}$.

\subsubsection{Incidente de arguição de inconstitucionalidade}

A sistemática atribuída à arguição de inconstitucionalidade (arts. 948 e 949) não trouxe inovações em relação ao CPC de 1973, operando-se a solução do incidente de maneira quase idêntica ao que já era previsto. Desse modo, se antes a arguição tinha pouca relevância prática nos Tribunais de Segunda Instância, é possível que o mesmo se repita agora, ainda mais porque, como visto acima, o Supremo Tribunal Federal tornou-se, acertadamente diga-se de passagem, o protagonista maior dessa arena.

\subsubsection{Incidente de resolução de demandas repetitivas}

Trata-se de outra novidade do CPC de 2015. Segundo os arts. 976 e seguintes do CPC de 2015, esse incidente é cabível quando houver, simultaneamente, efetiva repetição de processos que contenham controvérsia sobre a mesma questão de direito e risco de ofensa à isonomia e à segurança jurídica. É o que ocorre, por exemplo, nas ações que discutam a aplicação de índices de correção monetária, questões tributárias, reajuste de tarifas públicas ou de planos de saúde, etc.

O pedido de instauração pode ser feito pelo juiz relator, pelas partes, pelo Ministério Público ou, ainda, pela Defensoria Pública. O julgamento do incidente cabe a um colegiado maior, segundo o regimento interno de cada Tribunal.

Antes do julgamento, porém, deve o colegiado maior admitir o recurso, hipótese em que ficarão suspensos os processos pendentes, individuais ou coletivos, que tramitam no Estado

73 Afinal, o "objetivo do incidente de assunção de competência é prevenir ou dirimir controvérsia a respeito de matéria (art. $947, \S 4^{\circ}, \mathrm{CPC}$ ) e orientar os membros do tribunal e os juízes a ele submetidos mediante a formação de precedente ou de jurisprudência vinculante (arts. 927, III, e 947, § $3^{\circ}$, CPC)". MARINONI, Luiz Guilherme; ARENHART, Sérgio Cruz; MITIDIERO, Daniel. Novo código de processo civil comentado. São Paulo: Revista dos Tribunais, 2015, p. 889. 
ISSN 1981-3694

(DOI): $10.5902 / 1981369431054$

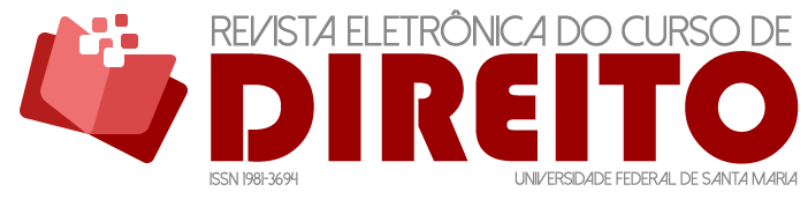

INFLUÊNCIA DA COMMON LAW NA IMPLANTAÇÃO DOS PRECEDENTES JUDICIAIS VINCULANTES NO BRASIL NA ERA DA SOCIEDADE DA INFORMAÇÃO

MARCELO GUERRA MARTINS GUSTAVO FILIPE BARBOSA GARCIA AUGUSTO TAVARES ROSA MARCACINI

ou na Região (em se tratando da Justiça Federal). Se o julgamento não ocorrer dentro de 1 (um) ano, cessará a suspensão dos processos.

Julgado o incidente, a tese jurídica será aplicada a todos os processos individuais ou coletivos que versem sobre idêntica questão de direito e que tramitem na área de jurisdição do respectivo Tribunal (stare decisis), aplicação essa que se estende aos casos futuros que apresentem idêntica questão de direito, salvo revisão da tese (overruling).

E, a teor do disposto no $\S 3^{\circ}$ do art. 982 do CPC de 2015, com objetivo de garantir a segurança jurídica, qualquer legitimado mencionado no art. 977, incisos II e III do Código, “poderá requerer, ao tribunal competente para conhecer do recurso extraordinário ou especial, a suspensão de todos os processos individuais ou coletivos em curso no território nacional que versem sobre a questão objeto do incidente já instaurado".

Esse expediente já foi aplicado pelo Supremo Tribunal Federal, na PET 7.001, conforme decisão proferida pela presidente da Corte, Ministra Cármen Lúcia, em questão oriunda do Tribunal Regional Federal da $4^{\text {a }}$ Região que tratava da repartição das receitas tributárias decorrentes do imposto de renda incidente na fonte sobre rendimentos pagos, a qualquer título, pelos Municípios a pessoas físicas ou jurídicas contratadas para a prestação de bens ou serviços. $\mathrm{Na}$ referida decisão, a Ministra ressaltou que o instituto em pauta se assemelha ao que é praticado em outros países, tais como o Group Litigation Order (Inglaterra), o Multidistrict Litigation (Estados Unidos da América e o Musterverfahren (Alemanha).

\subsubsection{Suspensão de processos por afetação de recurso extraordinário ou especial repetitivos}

O atual CPC de 2015 também passou a determinar a possibilidade de suspensão de todos os processos pendentes (inclusive os de primeira instância) sempre que houver multiplicidade de recursos extraordinários ou especiais com fundamento em idêntica questão de direito, a teor dos arts. $1.036, \S 1^{\circ}, \mathrm{c} / \mathrm{c} 1.037, \mathrm{II}$.

A afetação de um determinado recurso pode ocorrer por iniciativa do Presidente (ou Vice) de Tribunal local ou mesmo por iniciativa de um dos Ministros do STF ou do STJ. 0 efeito da afetação (que é a suspensão dos processos) pode ser local, quando ultimada no âmbito de Tribunal local, ou mesmo nacional, na hipótese de a afetação ter sido engendrada no âmbito do STF ou do STJ. 
ISSN 1981-3694

(DOI): $10.5902 / 1981369431054$

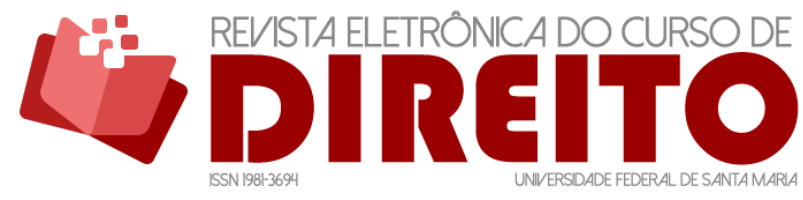

INFLUÊNCIA DA COMMON LAW NA IMPLANTAÇÃO DOS PRECEDENTES JUDICIAIS VINCULANTES NO BRASIL NA ERA DA SOCIEDADE DA INFORMAÇÃO

MARCELO GUERRA MARTINS GUSTAVO FILIPE BARBOSA GARCIA AUGUSTO TAVARES ROSA MARCACINI

Na sistemática dos arts. 543-B e 543-C do CPC de 1973, a suspensão ocorria apenas em relação aos processos já em fase de admissão de recurso extraordinário ou especial, ou seja, após o julgamento pelo Tribunal de Segunda Instância. Agora, a suspensão passa a ocorrer em todos os processos em trâmite, independentemente do estágio em que se encontrarem.

Trata-se de medida nitidamente acautelatória e que tem por claro objetivo evitar a divergência jurisprudencial, na medida em que, julgado o mérito do recurso afetado, a observância da tese de direito fixada pelo STF ou pelo STJ será obrigatória (stare decisis).

À luz do art. 1.039 do novo Código, decididos os recursos afetados, os órgãos colegiados declararão prejudicados os demais recursos versando sobre idêntica controvérsia ou os decidirão aplicando a tese firmada. E, negada a existência de repercussão geral no recurso extraordinário afetado, serão considerados automaticamente inadmitidos todos aqueles cujo processamento tenha sido sobrestado.

Publicado o acórdão paradigma, o art. 1.040 determina que: terão negado seguimento os recursos extraordinários ou especiais sobrestados na origem, se o acórdão recorrido coincidir com a orientação superior adotada pelo STF ou STJ (inciso I); o órgão que proferiu o acórdão recorrido, na origem, reexaminará o processo se o acórdão recorrido contrariar a orientação superior (inciso II); os processos suspensos em primeiro e segundo graus de jurisdição retomarão o curso para julgamento e aplicação da tese firmada pelo STF ou STJ.

Enquanto as providências constantes dos incisos I e II já eram aplicáveis sob a égide do CPC/73, o estatuído no inciso III, conforme acima já dito, mais uma vez revela e reforça a adoção do stare decisis no direito processual brasileiro.

\section{BREVES COMENTÁRIOS CRÍTICOS ACERCA DO TEMA}

Há vários motivos, como já apontado no correr deste breve estudo, que indicam a necessidade e a oportunidade de manter uniforme o entendimento jurisprudencial sobre 0 sentido das normas jurídicas. Por outro lado, ponderações merecem ser feitas sobre a adoção de mecanismos legais tendentes a essa finalidade. A jurisprudência é, essencialmente, entre as fontes do Direito, aquela que lhe empresta dinamismo, moldando leis estáticas e paradas no tempo à realidade social do presente e, especialmente, às peculiaridades do caso concreto sobre o qual aquelas normas são aplicadas, muitas vezes fazendo-lhes uma releitura do seu sentido, finalidade e extensão. Após comentar essa função dinâmica da função jurisdicional, Barbosa Moreira acrescenta que: 
ISSN 1981-3694

(DOI): 10.5902/1981369431054

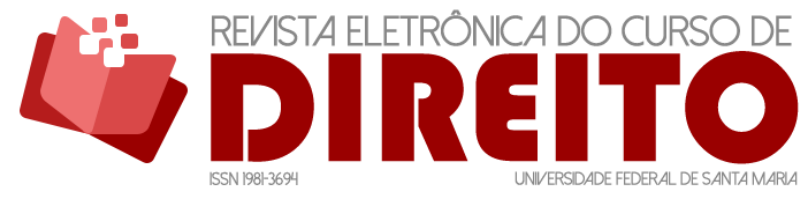

INFLUÊNCIA DA COMMON LAW NA IMPLANTAÇÃO DOS PRECEDENTES JUDICIAIS VINCULANTES NO BRASIL NA ERA DA SOCIEDADE DA INFORMAÇÃO

MARCELO GUERRA MARTINS GustaVO FILIPE BARBOSA GARCIA AUGUSTO TAVARES ROSA MARCACINI

Outro é, pois, o fenômeno que se tem em vista quando se alude à conveniência de adotar medidas tendentes à uniformização dos pronunciamentos judiciais. Liga-se ele ao fato da existência, no aparato estatal, de uma pluralidade de órgãos judicantes que podem ter (e com frequência têm) de enfrentar iguais questões de direito e, portanto, de enunciar teses jurídicas em idêntica matéria. Nasce daí a possibilidade de que, num mesmo instante histórico - sem variação das condições culturais, políticas, sociais, econômicas, que possa justificar a discrepância - a mesma regra de direito seja diferentemente entendida, e a espécies semelhantes se apliquem teses jurídicas divergentes ou até opostas. Assim se compromete a unidade do direito - que não seria posta em xeque, muito ao contrário, pela evolução homogênea da jurisprudência dos vários tribunais - e não raro se semeiam, entre os membros da comunidade, o descrédito e o cepticismo quanto à efetividade da garantia jurisdicional ${ }^{74}$.

Também é importante destacar o quão complexo é manter a obediência a tais orientações, uma vez que sejam uniformizadas no seio de um ou outro Tribunal, ou mesmo nas cortes superiores. É certamente mais fácil tentar afirmar a vinculação dos precedentes na lei do que, na realidade, efetivar tal vinculação. Como anota Zulmar Duarte, em texto recente:

Não é tarefa fácil "aplicar" os precedentes no cadinho dos casos, que exige a extração dos motivos determinantes (ratio decidendi) da decisão de ontem (precedente), para que sua trama seja estendida para resolver temas similares que se apresentam no processo de hoje. Essa atividade não se resolve com o mero etiquetamento do precedente ao caso, pois os motivos determinantes do precedente são textos que serão objeto de interpretação pelo juiz do caso subsequente, inclusive para eventualmente afastar sua regência. $E$ aí, o adequado funcionamento do regime de precedentes passa tanto por sua aplicação aos casos com identidade jurídica, quanto por seu afastamento se verificada diversidade significativa (distinguishing), como e principalmente por sua superação em situações que seu padrão decisório não seja mais adequado (overruling) ${ }^{75}$.

Aliás, a própria necessidade que teve o legislador nacional em determinar expressamente na lei a observância do precedente (distanciando-se, pois, do modelo "original", em que o respeito à jurisprudência é cultural) já aponta alguma dificuldade de importação dos institutos de um ordenamento jurídico a outro. Ademais, o modelo criado em nosso país abre margem ao questionamento sobre os limites precisos entre a atividade de julgar e a de legislar. Estabelecer preceitos gerais e abstratos, com vinculação para o futuro, não seria uma atividade legislativa? É o que, por exemplo, sustenta Nelson Nery Junior, em recente entrevista:

\footnotetext{
${ }^{74}$ MOREIRA, José Carlos Barbosa. Comentários ao código de processo civil, vol. V, 11. ed. Rio de Janeiro: Forense, 2003, p. 4-5.

75 DUARTE, Zulmar. O juiz e a superação do precedente: anticipatory overruling. Disponível em $<$ https:// www.jota.info/colunas/novo-cpc/juiz-e-a-superacao-do-precedente-antecipatory-overruling16102017>. Acesso em: 23 out. 2017.
} 
ISSN 1981-3694

(DOI): 10.5902/1981369431054

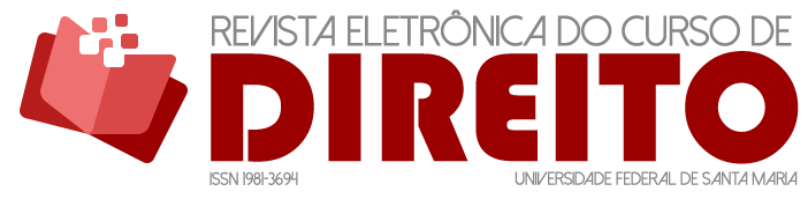

INFLUÊNCIA DA COMMON LAW NA IMPLANTAÇÃO DOS PRECEDENTES JUDICIAIS VINCULANTES NO BRASIL NA ERA DA SOCIEDADE DA INFORMAÇÃO

MARCELO GUERRA MARTINS GUSTAVO FILIPE BARBOSA GARCIA AUGUSTO TAVARES ROSA MARCACINI

Discutimos durante nove anos para chegar ao regramento que temos hoje na Constituição que diz quando o Supremo pode baixar uma súmula vinculante. Porque isso é tarefa legislativa, baixar um texto normativo vinculativo com eficácia geral e abstrata - isso é lei. Então para o Judiciário legislar, desculpe, precisa de autorização da Constituição. Aí vem o CPC com a mão do gato, de contrabando, bota algo na lei ordinária que deveria ter previsão constitucional ${ }^{76}$.

Ainda que, ao menos nesse momento, não vislumbremos alguma mácula de inconstitucionalidade no sistema de precedentes do atual CPC, é certo que a discussão acerca desse dilema não é nova e comporta ainda muitas reflexões. Aliás, já faz tempo que Frederico Marques, repontando-se a comentários de João Mendes Junior, noticia que os assentos dos tribunais haviam sido abolidos com a proclamação da República, por considerar-se na ocasião que tal aproximação de funções judiciárias e legislativas era incompatível com o regime republicano ${ }^{77}$.

O anteprojeto do Código de Processo Civil de 1973 também "pretendera consagrar solução inspirada no antigo direito português, a dos assentos vinculativos"78. Todavia "tal sistemática foi criticada em sede doutrinária, antes de mais nada, por inconstitucional"79, sendo sugerida a supressão de todo o capítulo pela comissão revisora, que na ocasião compreendeu a eficácia vinculativa dos assentos como contrária à Constituição".

\section{CONCLUSÃO}

A era da sociedade da informação facilitou e, com isso, intensificou a comunicação entre os povos, principalmente após a consolidação da internet nos anos 1990. Essa densa, crescente e ininterrupta circulação de ideias, informações e conhecimento vem contribuindo para que os ordenamentos jurídicos ao redor do mundo, inclusive com origens históricas diversas (casos da common law e da civil law), influenciem-se mutuamente de um modo ainda mais intenso e muitíssimo mais rápido do que já ocorreu no passado.

\footnotetext{
76 NERY JUNIOR, Nelson, "Núcleo duro do novo CPC é inconstitucional", diz jurista (entrevista concedida a Barbara Pombo). JOTA, disponível em: <https://jota.info/justica/nucleo-duro-novo-cpc-einconstitucional-diz-jurista-21122016>. Publicado em: $21 \mathrm{dez}$. 2016. Acesso em: 16 out. 2017. Em tom igualmente crítico, v. STRECK, Lenio Luiz; ABBOUD, Georges. O que é isto - o sistema (sic) de precedentes no CPC?, Disponível em: <https://www.conjur.com.br/2016-ago-18/senso-incomum-istosistema-sic-precedentes-cpc>. Acesso em: 17 out. 2017.

77 MARQUES, José Frederico, op. cit., p. 104.

78 MOREIRA, José Carlos Barbosa, op. cit., p. 07.

79 Ibidem.
} 
ISSN 1981-3694

(DOI): $10.5902 / 1981369431054$

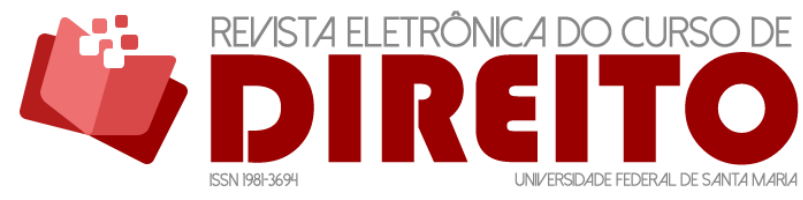

INFLUÊNCIA DA COMMON LAW NA IMPLANTAÇÃO DOS PRECEDENTES JUDICIAIS VINCULANTES NO BRASIL NA ERA DA SOCIEDADE DA INFORMAÇÃO

MARCELO GUERRA MARTINS GUSTAVO FILIPE BARBOSA GARCIA AUGUSTO TAVARES ROSA MARCACINI

É o que vem acontecendo com o processo civil brasileiro no que se refere à introdução dos precedentes judiciais vinculantes, cuja finalidade maior é proporcionar a uniformização da jurisprudência. Não obstante esse desiderato ser antigo, até criação do instituto da súmula vinculante, por meio da Emenda Constitucional 45/2004, os dispositivos legais disponíveis e que, em tese, contribuiriam para uniformizar a jurisprudência, tiveram baixa ou nenhuma eficácia.

Com efeito, o arcabouço legislativo criado após a Emenda Constitucional 45/2004 inseriu no ordenamento pátrio ferramentas indutoras da uniformização jurisprudencial, tais como: súmulas vinculantes, repercussões gerais do STF e recursos repetitivos do STJ, havendo nessas duas últimas hipóteses o sobrestamento, nas Instâncias Inferiores, dos processos que tratem da mesma matéria para aguardarem a decisão do paradigma pelo STF ou pelo STJ, a fim de que todos recebam decisão no mesmo sentido.

O Código de Processo Civil de 2015 não apenas encampou, mas, sobretudo, aperfeiçoou tais ferramentas. Nessa linha, em seu art. 926 dispôs que os Tribunais devem uniformizar sua jurisprudência e mantê-la estável, íntegra e coerente. Encontra-se expressa no art. 927 a obrigatoriedade de juízes e Tribunais seguirem as orientações emanadas das Instâncias Superiores expressas em súmulas vinculantes, decisões oriundas do controle concentrado de constitucionalidade, acórdãos em incidente de assunção de competência ou de resolução de demandas repetitivas e em julgamento de recursos extraordinário e especial repetitivos, bem como os enunciados das demais súmulas do STF em matéria constitucional e do STJ em matéria infraconstitucional. 0 art. 927 ainda prevê que juízes e Tribunais devem seguir a orientação do Plenário ou do Órgão Especial aos quais estiverem vinculados.

Nitidamente o Código de 2015 teve a intenção de positivar institutos como stare decisis, distinguishing e overruling, todos originados no sistema da common law, a teor do previsto no art. $489, \S 1^{\circ}, \mathrm{VI}$ que passou a considerar não fundamentada (portanto, nula) qualquer decisão judicial, seja interlocutória, sentença ou acórdão, que deixar de seguir enunciado de súmula, jurisprudência ou precedente invocado pela parte, sem demonstrar a existência de distinção no caso em julgamento ou a superação do entendimento.

Conforme visto no texto, uma jurisprudência uniforme pode ser capaz de fortalecer no ambiente institucional brasileiro as seguintes características: isonomia, segurança jurídica, utilização racional do Poder Judiciário (com ganhos de eficiência) e a impessoalidade na aplicação da lei, todos valores constitucionais de alto relevo, cuja presença inegavelmente fortalece o regime republicano, além de gerar efeitos econômicos positivos. 
ISSN 1981-3694

(DOI): $10.5902 / 1981369431054$

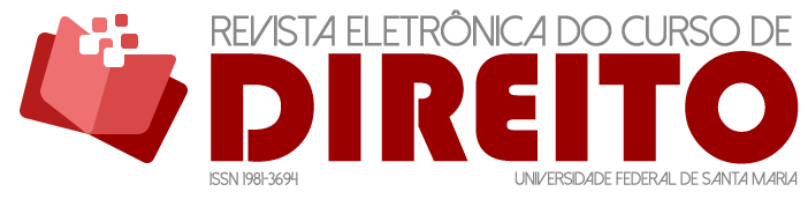

INFLUÊNCIA DA COMMON LAW NA IMPLANTAÇÃO DOS PRECEDENTES JUDICIAIS VINCULANTES NO BRASIL NA ERA DA SOCIEDADE DA INFORMAÇÃO

MARCELO GUERRA MARTINS GUSTAVO FILIPE BARBOSA GARCIA AUGUSTO TAVARES ROSA MARCACINI

Nesse diapasão, a inserção dos mecanismos de uniformização jurisprudencial vem representando, desde a Emenda 45/2004, efetivos avanços institucionais que, ao menos em tese, são aptos a proporcionar, ainda que não imediatamente, uma significativa melhora na qualidade do serviço jurisdicional.

\section{REFERÊNCIAS}

AMARAL, Gustavo. Direito, escassez \& escolha. Rio de Janeiro: Renovar, 2001.

AMERICANO, Jorge. Comentários ao código de processo civil do Brasil, 4. vol., São Paulo: Saraiva, 1960.

ARAÚJO, Francisco Rossal de; BRANDENBURG, Marceli. Sistemas abertos e fechados: uma breve comparação entre os sistemas da common law e civil law. Justiça do Trabalho, ano 32, n. 384, dez. 2015, p. 07-22.

ATALIBA, Geraldo. República e constituição. 2. ed., 4. tir., São Paulo: Malheiros, 2007.

AZEVEDO NETO, Floriano Marques de. 0 direito administrativo no sistema de base romanística e de common law. Revista de Direito Administrativo, v. 268, jan./abr. 2015, p. 55-81.

BRASIL. Código de Processo Civil de 1939. Disponível em:

<http://www.planalto.gov.br/ccivil_03/decreto-lei/1937-1946/Del1608.htm >. Acesso em: 24 out. 2017.

BRASIL. Código de Processo Civil de 1973. Disponível em:

<http://www.planalto.gov.br/ccivil_03/leis/L5869.htm>. Acesso em: 24 out. 2017.

BRASIL. Código de Processo Civil de 2015. Disponível em:

<http://www.planalto.gov.br/ccivil_03/_ato2015-2018/2015/lei//13105.htm>. Acesso em: 24 out. 2017.

BRASIL. Constituição Federal (1988). Constituição da República Federativa do Brasil. Diário Oficial da União. Brasília. DF. 5 out. 1988. Disponível em:

<http://www.planalto.gov.br/ccivil_03/Constituicao/Constituicao.htm>. Acesso em: 21 nov. 2018.

BRASIL. Tribunal Regional Federal da $5^{a}$ Região. Acórdão que solucionou incidente de uniformização de jurisprudência. Apelação em Mandado de Segurança $n^{\circ}$ 2000.05.00.047509-0. Acctur Câmbio e Turismo Ltda. e Banco Central do Brasil. Relator: Desembargador Federal Rogério Fialho Moreira. $1^{\circ}$ de julho de 2008. Disponível em: <http://www.trf5.gov.br/archive/2008/08/200005000475090_20080804.pdf>. Acesso em: 21 nov. 2018. 
BRASIL. Supremo Tribunal Federal. Decisão proferida pela Ministra Presidente em SIRDR Suspensão Nacional em Incidente de Resolução de Demandas Repetitivas. Petição $n^{\circ} 7.001$. União Federal e Tribunais Regionais Federais do País. Relatora: Ministra Cármen Lúcia. 15 de dezembro de 2017. Disponível em:

<http: //portal.stf.jus.br/processos/downloadPeca. asp?id=313517168\&ext=.pdf>. Acesso em: 21 nov. 2017.

BRASIL. Supremo Tribunal Federal. Regimento Interno. Disponível em: <http://www.stf.jus.br/ arquivo/cms/legislacaoRegimentolnterno/anexo/RISTF.pdf>. Acesso em: 09 jul. 2017.

BRASIL. Supremo Tribunal Federal. Súmulas vinculantes. Disponível em: <http: //www.stf.jus.br/arquivo/cms/jurisprudenciaSumulaVinculante/anexo/Enunciados_Sumul a_Vinculante_STF_Completo.pdf $>$. Acesso em: 16 jul. 2017.

CASTELLS, Manuel. A galáxia da internet. Trad. Maria Luiza X. de A. Borges. Rio de Janeiro: Zahar, 2003.

COSTA, Alfredo de Araújo Lopes da. Manual elementar de direito processual civil. Rio de Janeiro: Forense, 1956.

COSTA, Mário Júlio de Almeida. História do direito português. Coimbra: Almedina, 2002.

COSTA, Regina Helena. Repercussão geral em matéria tributária: primeiras reflexões. In: PAULSEN, Leandro (coord.). Repercussão geral no recurso extraordinário. Porto Alegre: Livraria do Advogado, 2011, p. 109-117.

CUNHA, Leonardo Carneiro da. A função do Supremo Tribunal Federal e a força de seus precedentes: enfoque das causas repetitivas. In: PAULSEN, Leandro (coord.). Repercussão geral no recurso extraordinário. Porto Alegre: Livraria do Advogado, 2011, p. 57-73.

DALLARI, Dalmo de Abreu. O poder dos juízes. São Paulo: Saraiva, 1996.

DECLARAÇÃO dos Direitos do homem e do cidadão (1789). França. 26 de agosto de 1789. Disponível em: <http://www.direitoshumanos.usp.br/index.php/Documentos-anteriores\%C3\%A0-cria\%C3\%A7\%C3\%A3o-da-Sociedade-das-Na\%C3\%A7\%C3\%B5es-at\%C3\%A9-1919/declaracaode-direitos-do-homem-e-do-cidadao-1789.html>. Acesso em: 21 nov. 2018.

DUARTE, Zulmar. 0 juiz e a superação do precedente: anticipatory overruling. Disponível em <https://www.jota.info/colunas/novo-cpc/juiz-e-a-superacao-do-precedente-antecipatoryoverruling-16102017>. Publicado em: 16 out. 2017. Acesso em: 23 out. 2017.

DUTRA, Deo de Campos. Da ortodoxia à crítica: teorias da comparação jurídica. Revista Brasileira de Direito, vol. 14, n. 1, jan./abr. 2018, p. 189-211.

ESTADOS UNIDOS DA AMÉRICA. U.S. Supreme Court. Decisão acerca da possibilidade de o órgão acusador apresentar novas evidências na fase de cumprimento da sentença penal. 501. U.S. 808,827 (1991). Payne v. Tennessee. Relatora: Sandra Day O'Connor. 27 de junho de 1991. Disponível em: <https://supreme.justia.com/cases/federal/us/501/808/case.html>. Acesso em: 21. Nov. 2018. 
ISSN 1981-3694

(DOI): $10.5902 / 1981369431054$

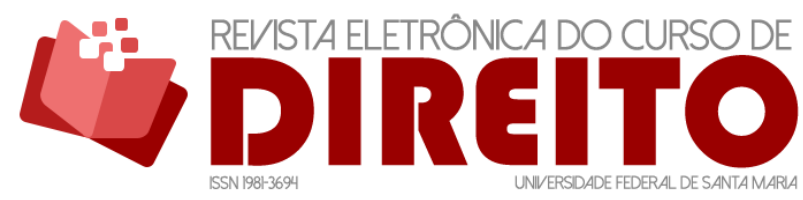

INFLUÊNCIA DA COMMON LAW NA IMPLANTAÇÃO DOS PRECEDENTES JUDICIAIS VINCULANTES NO BRASIL NA ERA DA SOCIEDADE DA INFORMAÇÃO

MARCELO GUeRRA MARTINS GUSTAVO FILIPE BARBOSA GARCIA AUGUSTO TAVARES ROSA MARCACINI

ESTADOS UNIDOS DA AMÉRICA. U.S. Supreme Court. Rules of the Supreme Court of the United States. Disponível em:

<https://www.supremecourt.gov/filingandrules/2017RulesoftheCourt.pdf>. Acesso em: 21 nov. 2018.

FORGIONI, Paula A. Fundamentos do antitruste. 8. ed., São Paulo: Revista dos Tribunais, 2015.

FRANKENBERG, Günter. Critical comparisons: re-thinking comparative law. Harvard International Law Journal, vol. 26, n. 2, 1985, p. 411-455.

GARAPON, Antoine; PAPAPOULOS, loannis. Julgar nos Estados Unidos e na França: cultura jurídica francesa e common law em uma perspectiva comparada. Trad. Regina Vasconcelos. Rio de Janeiro: Lumen Juris, 2008.

GILISSEN, John. Introdução histórica ao direito. Trad. A. M. Hespanha e L. M. Macaísta Malheiros. Lisboa: Fundação Calouste Gulbenkian, 1988.

GONÇALVES, Albenir Itaboraí Querubini. O direito brasileiro e a inovação na consolidação de um sistema de precedentes recursais. Revista Eletrônica do Curso de Direito da UFSM, v. 6, n. 3, 2011.

HAMILTON, Peter J. The civil law and the common law. Harvard Law Review, v. 36, n. 2, p. 180-192.

KOTZ, Hein. The Function of Comparative Law in the Development of a European Common Law. Asia Pacific Law Review, 45, 1994, p.45-52.

LEAL, Saul Tourinho. A repercussão geral em matéria tributária segundo o Supremo Tribunal Federal. Revista Dialética de Direito Tributário, n. 165, jun. de 2009, p. 109-116.

LEGRAND, Pierre. Negative comparative law. Journal of Comparative Law, v. 10, n. 2, 2015.

LÉVY, Pierre. Cyberculture. Trad. p/ ingles de Robert Bononno. Minneapolis: University of Minesota Press, 2001.

LISBOA, Roberto Senise. O consumidor na sociedade da informação. In: PAESANI, Liliana Minardi (Coord.). 0 direito na sociedade da informação. São Paulo: Atlas, 2007, p. 113-142.

LOPES, José Reinaldo de Lima; QUEIROZ, Rafael Mafei Rabelo; ACCA, Thiago dos Santos. Curso de história do direito. 2. ed., São Paulo: Método, 2009.

MARINONI, Luiz Guilherme. A ética dos precedentes: justificativa do novo CPC. São Paulo: Revista dos Tribunais, 2016.

MARINONI, Luiz Guilherme; ARENHART, Sérgio Cruz; MITIDIERO, Daniel. Novo código de processo civil comentado. São Paulo: Revista dos Tribunais, 2015. 
ISSN 1981-3694

(DOI): $10.5902 / 1981369431054$

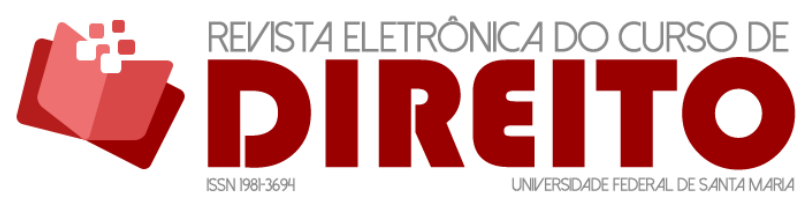

INFLUÊNCIA DA COMMON LAW NA IMPLANTAÇÃO DOS PRECEDENTES JUDICIAIS VINCULANTES NO BRASIL NA ERA DA SOCIEDADE DA INFORMAÇÃO

MARCELO GUeRRa MARTINS GUSTAVO FILIPE BARBOSA GARCIA AUGUSTO TAVARES ROSA MARCACINI

MARQUES, José Frederico. Instituições de direito processual civil, vol. IV, 3. ed., Rio de Janeiro: Forense, 1969.

MATTELART, Armand. The information society. Trad. p/ inglês Susan G Taponier e James A. Cohen. London: SAGE Publications, 2003,

MELLO, Maria Chaves de. Dicionário jurídico português inglês - inglês português. 10. ed., São Paulo: Método, 2012.

MICHELS, Gilson Wessler. Desenvolvimento e sistema tributário. In: BARRAL, Welber (org.). Direito e desenvolvimento: análise da ordem jurídica brasileira sob a ótica do desenvolvimento. São Paulo: Singular, 2005, p. 225-258.

MOREIRA, José Carlos Barbosa. Comentários ao código de processo civil, vol. V, 11. ed., Rio de Janeiro: Forense, 2003.

NERY JUNIOR, Nelson, "Núcleo duro do novo CPC é inconstitucional", diz jurista (entrevista concedida a Barbara Pombo). JOTA, disponível em: <https://jota.info/justica/nucleo-duro-novocpc-e-inconstitucional-diz-jurista-21122016>. Publicado em: $21 \mathrm{dez}$. 2016. Acesso em: 16 out. 2017.

PINHEIRO, Armando Castelar. PIB potencial e segurança jurídica no Brasil. In: SICSÚ, João; MIRANDA, Pedro (orgs.). Crescimento econômico: estratégias e instituições Rio de Janeiro: IPEA, 2009, p. 25-53.

PORTUGAL. Ordenações afonsinas. Lisboa: Fundação Calouste Gulbenkian, 1984.

POUND, Roscoe. The spirit of the common law. Francestown: Marshall Jones Company Publishers, 1921.

RÁO, Vicente. 0 direito e a vida dos direitos, vol. 1, 3. ed., São Paulo: Revista dos Tribunais, 1991.

SÃO PAULO. Código do processo civil e commercial do Estado de São Paulo, Lei n. 2.421, de 14 de janeiro de 1930. Disponível em:

<https://www.al.sp.gov.br/repositorio/legislacao/lei/1930/lei-2421-14.01.1930.html>. Acesso em: 17 out. 2017.

SIQUEIRA JÚNIOR, Paulo Hamilton. Habeas data: remédio jurídico da sociedade da informação. In: PAESANI, Liliana Minardi (Coord.). 0 direito na sociedade da informação. São Paulo: Atlas, 2007, p. 251-274.

SOARES, Guido Fernando da Silva. Common law: introdução ao direito dos EUA. 2. ed., São Paulo: Revista dos Tribunais, 2000.

STRECK, Lenio Luiz; ABBOUD, Georges. 0 que é isto - o sistema (sic) de precedentes no CPC?. Disponível em: <https://www.conjur.com.br/2016-ago-18/senso-incomum-isto-sistema-sicprecedentes-cpc>. Publicado em: 18 ago. 2016. Acesso em: 17 out. 2017. 
ISSN 1981-3694

(DOI): $10.5902 / 1981369431054$

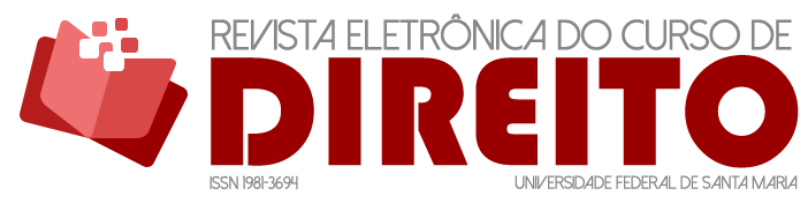

INFLUÊNCIA DA COMMON LAW NA IMPLANTAÇÃO DOS PRECEDENTES JUDICIAIS VINCULANTES NO BRASIL NA ERA DA SOCIEDADE DA INFORMAÇÃO

MARCELO GUERRA MARTINS GuSTAVO FILIPE BARBOSA GARCIA AUGUSTO TAVARES ROSA MARCACINI

THAYER, Ezra R. Thayer. Judicial legislation: its legitimate function in the development of the common law. Harvard Law Review, vol. 5, n. 4, nov. 1891, p. 172-201.

TUCCI, José Rogério Cruz e; AZEVEDO, Luiz Carlos de. Lições de história do processo civil lusitano. São Paulo: Revista dos Tribunais, 2009.

TOFFLER, Alvin. A terceira onda. 18. ed., São Paulo: Record. 1980.

UNITED NATIONS. Economic and Social Commission for Western Asia. Information Society measurement: building a common benchmarking model for the ESCWA Region. New York: United Nations, 2011. Disponível em: <https://www.unescwa.org/publications/information-societymeasurement-building-common-benchmarking-model-escwa-region>. Acesso em: 30 jul. 2018.

WAMBIER, Teresa Arruda Alvim. Interpretação da lei e de precedentes - civil law e commom law. In: ADEODATO, João Maurício; BITTAR, Eduardo C. B. (orgs.). Filosofia e teoria geral do direito: estudos em homenagem a Tercio Sampaio Ferraz Júnior pelo seu septuagésimo aniversário. São Paulo: Quartier Latin, 2011, p. 1061-1073.

\section{COMO FAZER A REFERÊNCIA DO ARTIGO (ABNT):}

MARTINS, Marcelo Guerra;GARCIA, Gustavo Filipe Barbosa;MARCACINI, Augusto Tavares Rosa. Influência da common law na implantação dos precedentes judiciais vinculantes no brasil na era da sociedade da informação. Revista Eletrônica do Curso de Direito da UFSM, Santa Maria, RS, v. 13, n. 3, p. 1098-1133, dez. 2018. ISSN 1981-3694. Disponível em: < https://periodicos.ufsm.br/revistadireito/article/view/31054 >. Acesso em: dia mês. ano. doi: http://dx.doi.org/10.5902/1981369431054 . 